\title{
A revision of Baeckea (Myrtaceae) in eastern Australia, Malesia and south-east Asia
}

\author{
A.R. Bean
}

\begin{abstract}
Bean, A.R. (Queensland Herbarium, Meiers Road, Indooroopilly, Queensland 4068) 1998. A revision of Baeckea (Myrtaceae) in eastern Australia, Malesia and south-east Asia. Telopea 7(3): 245-268. All species from eastern Australia, Malesia and south-east Asia belonging to Baeckea sens. str. are listed with full synonymy, distribution maps and notes on habitat. Baeckea stenophylla F. Muell. is reduced to synonymy under B. frutescens L. Three new species from Queensland and New South Wales are described and illustrated: Baeckea trapeza, Baeckea omissa and Baeckea kandos; and the new combination B. latifolia is made, based on B. gunniana var. latifolia Benth. Keys are provided for the identification of the genera of Subtribe Baeckeinae and for all species of Baeckea from eastern Australia, Malesia and south-east Asia. A list of excluded names for this region is given.
\end{abstract}

\section{Introduction}

Bentham (1865) established a broad concept for the genus Baeckea, which prevailed for over a century. However, recent studies (Trudgen 1986; Trudgen 1987; Bean 1995; Bean 1997a) have shown that many species previously placed in Baeckea should be excluded from it, and placed in new or reinstated genera. Hence the newly circumscribed genus Baeckea comprises only 14 species, all confined to Australia, except for the type species, B. frutescens L., which extends from eastern Australia through Malesia to southern China.

\section{Geography and ecology}

Baeckea is widespread along the coast and tablelands of south-eastern Australia. Two species occur in Western Australia, both in the cool, high-rainfall areas near Albany, in heathy swamps. Baeckea is absent from South Australia and Northern Territory. The northern limit of the genus (excluding $B$. frutescens) is reached by $B$. trapeza at Blackdown Tableland $\left(23^{\circ} 45^{\prime} \mathrm{S}\right.$, c. $800 \mathrm{~m}$ altitude), and the northern coastal limit is achieved by B. imbricata at Cooloola National Park (26 04'S).

Most species of Baeckea apparently require a high water table, and hence they are found in swamps and heathlands; however, two species (B. brevifolia and B. kandos) commonly grow on sandstone rocks. With the exception of B. frutescens, Baeckea species are of temperate climates. Greatest species diversity is reached on the Central Coast and Central Tablelands of New South Wales. Two species (B. gunniana and B. utilis) extend to alpine communities, above 2000 metres altitude, near Mt Kosciusko (Thompson and Gray 1981).

\section{Materials and methods}

This study is based upon an examination of herbarium material from A, BM, BRI, CANB, G, GH, HAL, HO, K, L, MEL, NE, NSW and QRS, as well as photographs and 
microfiche from K, LINN and G-DC. Most species have been seen in the field to examine bark, habit and habitat, and to collect suitable floral material for later herbarium study. Measurements of leaves and fruits, and the presence or absence of oil glands on various plant structures, are based on dried herbarium specimens, and the leaves measured are those on flowering branches. Measurements of floral parts are based on material preserved in spirit, or reconstituted by boiling them in water. A minimum of three collections per taxon, from throughout the geographical range of the taxon, are used to compile floral data. Distribution maps indicate the presence of a herbarium specimen record within a given $0.5 \times 0.5$ degree square (corresponding to the 1: 100000 map sheets). Species are arranged in perceived systematic order.

\section{Taxonomy}

Key (for eastern and northern Australia*, New Caledonia, Malesia and south-east Asia) to the genera comprising Subtribe Baeckeinae

1 Ovules and seeds reniform, not angular; ovary 3-locular

Ovules and seeds discoid, angular; ovary 2- or 3-locular 4

2 Some stamens opposite centre of petals Euryomyrtus

No stamens opposite centre of petals 3

3 Ovules 2 per loculus; stamens 5-8 Ochrosperma

Ovules 8-13 per loculus; stamens 14-18 Triplarina

4 Stamens fused into 5 antesepalous bundles Astartea Stamens completely free 5

5 Anthers adnate, dehiscing by pores or short divergent slits Babingtonia Anthers versatile, dehiscing by long parallel slits 6

6 Inflorescences 1-flowered; peduncles $<0.5 \mathrm{~mm}$ long or absent; sepals simple; ovary 2-locular, rarely 3-locular Baeckea

Inflorescences 3-35-flowered; peduncles 3-9 $\mathrm{mm}$ long; sepals compound; ovary 3-locular genus nov.**

* includes Northern Territory, Queensland, New South Wales, Australian Capital Territory, Victoria and Tasmania.

**monotypic genus from Northern Territory, unpublished.

Baeckea L., Sp. Plant. 358 (1753)

Type: B. frutescens L.

Tjongina Adans., Fam. Pl. 2: 234 (1763), nom. illeg.

Type: Baeckea frutescens L.

Jungia Gaertn., Fruct. Sem. P1. 1: 175 (1788), nom. illeg. non Fabr. (1759); Baeckea sect. Jungia Baill., Hist. Pl. 6: 358 (1876).

Lectotype: Jungia imbricata Gaertn. (fide R. McVaugh, Taxon 5 (1956) 142) = Baeckea imbricata (Gaertn.) Druce 
Imbricaria Sm., Trans. Linn. Soc. London 3: 257 (1797), nom. illeg. non Juss. (1789).

Baeckea sect. Imbricaria Baill., Hist. Pl. 6: 358 (1876).

Lectotype: Imbricaria crenulata Sm. (fide R. McVaugh, Taxon 5 (1956) 141) = Baeckea imbricata (Gaertn.) Druce

Neuhofia Stokes, Bot. Mat. Med. 1: 439 (1812).

Type: Neuhofia rosmarinifolia, nom. illeg. (= Cedrela rosmarinus Lour.).

Schidiomyrtus Schauer, Linnaea 17: 237 (1843)

Baeckea sect. Schidiomyrtus (Schauer) F. Muell., Fragm. 1: 29-30 (1858)

Lectotype: Schidiomyrtus crenulata (Sm.) Schauer (fide R. McVaugh, Taxon 5 (1956) 146) = Baeckea imbricata (Gaertn.) Druce

Drosodendron M. Roemer, Fam. Nat. Syn. Monogr. 1: 140 (1846).

Type: Drosodendron rosmarinus (Lour.) M. Roemer (= Cedrela rosmarinus Lour.)

Mollia J.F. Gmel., nom. rej. (fide I.C.B.N. (1988) No. 4960).

Shrubs, all parts glabrous. Bark grey, scaly or papery, persistent. Branchlets more or less terete, with finely reticulate epidermis, shedding irregularly as branchlets expand; flanged or not. Leaves opposite, decussate, exstipulate, microphyllous, oil glands conspicuous, margins entire or denticulate. Inflorescences solitary, axillary. Flowers actinomorphic, bisexual, 5-merous. Peduncles absent or very short; pedicels terete. Bracteoles 2, conduplicate, caducous or rather persistent, leaving a prominent scar, marking the junction of pedicel and peduncle. Hypanthium obconical to campanulate, smooth, adnate to ovary, and continuing above ovary summit. Sepals simple or rarely compound, persistent, thin or occasionally with a thickened central area, margins entire or fimbriate. Stamens free, in a single whorl, shorter than petals. Filaments terete, tapering towards the apex; anthers versatile, dorsifixed, bilocular, opening by longitudinal slits; connective gland globular, smaller than anther cells. Ovary inferior, 2-locular (rarely 1- or 3-locular), ovules arranged in two longitudinal rows, perpendicular to long axis of placenta; placenta peltate. Style simple, terete, emerging through, but free from, the floral disc, lengthening after anthesis; stigma capitate, papillose. Fruits capsular, hemisperical to cylindrical, chartaceous to woody, crowned by persistent sepals, dehiscing loculicidally, valves included. Seeds discoid or cuboid, with rounded outer surface and flat sides, angular, surface finely reticulate or smooth, not arillate. Embryo with small cotyledons on a slender neck attached to a large radicle.

Key to species of Baeckea in eastern Australia and Malesia

1. Leaves linear, more than 6 times longer than wide 2

Leaves oblanceolate, elliptical or ovate, less than 6 times longer than wide $\quad . . . . .5$

2. Leaves in clusters at each node, ovary 2-3-locular 1. B. frutescens

Leaves solitary at each node, ovary always 2-locular 3

3. Stamens 5-6(-7); ovules 8-11 per loculus; leaves $0.8-1.2 \mathrm{~mm}$ wide

3. B. leptocaulis

Stamens 8-12; ovules 11-15 per loculus; leaves 0.5-1.0 mm wide 4

4. Leaves 6-17 $\mathrm{mm}$ long, apex acute to acuminate 2. B. linifolia

Leaves 3.3-5.8 mm long, apex obtuse 9. B. kandos 
5. Leaves sessile

Leaves petiolate 6

6. Leaves 1-1.5 times longer than wide (orbicular to broadly ovate)

Leaves 1.5-6 times longer than wide (oblanceolate to elliptical) 7

7. Leaf margins denticulate throughout 5. B. diosmifolia

Leaf margins entire, or denticulate near apex 8

8. Leaves $2.3-5.3 \mathrm{~mm}$ wide, flat 11. B. latifolia

Leaves 0.5-2.3 mm wide, concavo-convex 9

9. Pedicels $0.4-1.6 \mathrm{~mm}$ long 10

Pedicels 1.6-2.5 mm long 10. B. utilis

10. Stamens 4-6; ovary 1-locular 8. B. gunniana Stamens 8-11; ovary 2-locular 11

11. Leaves 1.8-3.3 mm long; hypanthium 1.2-2 mm long; ovules 11-12

7. B. omissa

Leaves 3.3-4.5 mm long; hypanthium 2-2.5 mm long; ovules 14-15

6. B. trapeza

1. Baeckea frutescens L., Sp. Pl.: 358 (1753).

Type: China: Guangzhou (Canton) Guangdong province, P. Osbeck s.n., 1750-1752 (holo LINN, microfiche BRI).

Baeckea chinensis Gaertn., Fruct. Sem. Pl. 1: 157, t. 31 (as B. sinensis) (1788).

Type: t. 31 in Fruct. Sem. Pl. 1

Cedrela rosmarinus Lour., Fl. Cochinch.: 160 (1790); Neuhofia rosmarinifolia Stokes, Bot. Mat. Med. 1: 439 (1812), nom. illeg.; Itea rosmarinus (Lour.) Schult. in Roem. \& Schult., Syst. Veg. 5: 408 (1819); Drosodendron rosmarinus (Lour.) M.Roemer, Fam. Nat. Syn. Monogr. 1: 138 (1846); Baeckea cochinchinensis Blume, Ann. Mus. Bot. LugdunoBatavum 1: 69 (1849), nom. illeg.

Type: 'Habitat frequenter in locis arenosis, ad boream sitis in Cochinchina. Vidi etiam sponte nascentem in insulis circa Macaum in China' (holo ?BM n.v.)

Baeckea cumingeana Schauer in Walp., Repert. Bot. Syst. 2: 920 (1843).

Type: 'in Malacca', H. Cuming 2269, 1837-1840 (holo K n.v., photo at BRI).

Baeckea ericoides Schltdl., Bot. Zeitung 4: 724 (1846).

Type: Sumatra littus, F.W. Junghuhn s.n., 1840-1842 (holo HAL).

Baeckea sumatrana Blume, Ann. Mus. Bot. Lugduno-Batavum 1: 69-70 (1849).

Type: Palembang, Sumatra. (holo L? n.v.)

Baeckea stenophylla F. Muell., Fragm. 1: 13 (1858), syn. nov.

Type: Queensland. Moreton Island, F. Mueller s.n., August 1855 (holo MEL [MEL 73046]) 
Shrub or tree to $8 \mathrm{~m}$ high. Bark grey, fibrous, persistent. Branchlets grey, segments flat, not flanged, margins entire; oil glands present or absent. Leaves in clusters at each node, linear, straight, plano-convex, not keeled, 5.5-11.5 mm long, $0.4-0.8 \mathrm{~mm}$ wide, oil glands visible on both surfaces, midvein not visible, margins entire, apex obtuse or acute, base narrowly cuneate; petioles $0.5-0.6 \mathrm{~mm}$ long. Peduncles absent or up to $0.2 \mathrm{~mm}$ long; pedicels $0.8-1.7 \mathrm{~mm}$ long; bracteoles narrowly lanceolate, c. $1.5 \mathrm{~mm}$ long, caducous before anthesis, apex acute, margins entire. Hypanthium obconical to campanulate, 1.5-2.2 mm long, smooth, fused to the ovary except distally. Sepals simple, semiorbicular, $0.4-0.9 \times 0.6-1.1 \mathrm{~mm}$, thin, apex obtuse, margins entire. Corolla up to $5 \mathrm{~mm}$ across; petals white, orbicular, $1.1-1.8 \mathrm{~mm}$ across, oil glands present, margins entire. Stamens 7-13, in groups of 1-3 opposite each hypanthium lobe, stamen opposite sepal shorter than remainder; filaments $0.5-0.8 \mathrm{~mm}$ long, not glandular; anthers versatile, c. $0.25 \mathrm{~mm}$ long, connective gland brown, c. one-quarter as long as anther cells. Style terete, c. $1.2 \mathrm{~mm}$ long at anthesis, stigma broadly capitate. Ovary 2- or 3-locular, roof of ovary concave, ovules 12-18 per loculus, arranged in two longitudinal rows on placenta. Fruit hemispherical to campanulate, $1.6-2.0 \times 2.3-2.5 \mathrm{~mm}$, valves inconspicuous, not woody, enclosed. Seeds c. $0.5 \mathrm{~mm}$ long, brown.

Distribution and habitat: $B$. frutescens is widespread from south-east Asia to Australia, including southern China (Guangdong, Guangxi, Fujian and Jiangxi provinces (Anon. 1972)), Thailand, Malaya, Sumatra, Borneo, Celebes, New Guinea, Queensland and New South Wales (Fig. 1). It is not known to occur in Java, Lesser Sunda Islands or the Philippines. It grows in deep sandy soils which are seasonally wet. In southern Queensland and New South Wales it occurs in heathland or sedgeland with Banksia spp., Gahnia sieberiana Kunth or Boronia falcifolia A. Cunn. On Cape York peninsula, it grows in Melaleuca woodland or 'scrub' of Asteromyrtus lysicephala (F. Muell. \& F.M. Bailey) Craven. In Malesia and south-east Asia, it grows on poor sandy or ultrabasic soils, in shrubland, often at high altitudes.

Phenology: flowering may occur in every month of the year, but the main period in Australia is October-February; with fruiting between February and August.

Notes: the type of B. stenophylla has a 2-locular ovary, and it has traditionally been separated from $B$. frutescens on this basis. However, flowers with 3-locular ovaries and 2-locular ovaries can be found on the same plant, and 3-locular ovaries are common in the geographical area considered to comprise B. stenophylla. Moreover, 2-locular specimens of $B$. frutescens from Malesia and south-east Asia can readily be found. There are no other correlated differences between 2-locular specimens and 3-locular specimens, hence $B$. stenophylla is reduced to synonymy under B. frutescens.

The type of Cedrela rosmarinus has not been seen by the present author, and the synonymy is based on the opinion of Merrill (1935).

Conservation status: B. frutescens is a common and widespread species.

Selected specimens: China: Botanic Gardens, Guangzhou, Yip 72, 15 Oct 1979 (BRI).

Thailand: Mt Luang, Udawn, Hennipman 3573, Jan 1966 (L).

Malaya: Klang Gates, Selangor, Balgooy 2732, 13 July 1975 (BRI); Gunong Padang, Whitmore FRI 12643, 19 Sep 1969 (A).

Borneo: Mengalong F. Res., Sabah, Madani E Ismail SAN 111384, 12 Sep 1985 (BRI); Mile 5 Rashna road, Nabawan, Sabah, Sundaling SAN 83864, Aug 1976 (K, KEP, L, SAR, SING).

Indonesia: Celebes: Selatan, E. side of Lake Matano, De Vogel 5855, 18 June 1979 (BRI); subdivision Malili, behind Noeha, Eyma 3348, Aug 1938 (L).

Irian Jaya: Tobie, Kebar Valley, Schram BW 7959, Nov 1958 (CANB, L, LAE).

Sumatra: Kota Pinang district, Toroes 4163, Apr 1933 (A). 
Papua-New Guinea: Green River, c. 140 km S of Vanimo, Waterhouse BMW2609 E Obedi, 16 May 1992 (BRI).

Australia: Queensland: Cook: Crystal Creek swamp, north-east of Vrylia Point, Godwin C2128, Aug 1981 (QRS); 3.5 km N of Massey Creek on Silver Plains station, Clarkson 3624, 11 Nov 1980 (BRI, DNA, K, NSW, PERTH, QRS); Olive River, Cape York peninsula, Webb E Tracey 13853, Sep 1974 (BRI, QRS). Port Curtis: Littabella N.P., c. 40 km NW of Bundaberg, Bean 7008, 18 Nov 1993 (A, BRI, L); Clinton Lowland, Shoalwater Bay, Thompson 81, 10 Feb 1992 (BRI, NSW, PERTH). Wide Bay: 1 km W of Dilli Village, Fraser Is., Bean 8087, 22 Nov 1994 (BRI, K, MEL). Moreton: Sippy Creek, Coaldrake QCC 96, 4 Jan 1951 (BRI).

New South Wales: North Coast: Tyagarah, 8 km NW of Byron Bay, Bean 7641, 23 Apr 1994 (BRI, L, MEL, NSW); Broadwater NP, north of Evans Head, Bean 8006, 12 Nov 1994 (BRI); Link Road, N of Sawtell, Bean 11737, Mar 1997 (BRI, NSW); Hat Head to Kinchela Creek, Briggs, Jan 1962 (NSW).

2. Baeckea linifolia Rudge, Trans. Linn. Soc. London 8: 297 (1807).

Type: New South Wales: 'prope Port Jackson in Nova Hollandia', collector unknown, undated (holo BM n.v., photo BRI).

Baeckea trichophylla Spreng., Syst. Veg. 4: 149 (1827); Baeckea linifolia f. trichophylla (Spreng.) Domin, Biblioth. Bot. 89: 450 (1928).

Type: Nov. Holl., F.W. Sieber 280, 1823 (iso G, GH, K n.v., photo BRI).

Baeckea linifolia var. brevifolia F.Muell. ex Benth., Fl. Austral. 3: 80 (1867).

Type: New South Wales. near Mt Imlay, F. Mueller s.n., undated (holo K n.v., photo BRI).

Shrub to $3 \mathrm{~m}$ high. Bark grey, scaly, persistent. Branchlets grey, segments flat, flanged, margins entire; oil glands absent or present. Leaves solitary at each node, linear, straight, concavo-convex to involute, not keeled, $6-17 \mathrm{~mm}$ long, $0.5-1.0 \mathrm{~mm}$ wide, oil glands visible on both surfaces, midvein not visible, margins entire, apex acute to acuminate, base cuneate; petioles c. $0.5 \mathrm{~mm}$ long. Peduncles absent or up to $0.4 \mathrm{~mm}$ long; pedicels $0.6-2.5 \mathrm{~mm}$ long, bracteoles linear, $1.6-3.3 \mathrm{~mm}$ long, caducous before anthesis, apex acuminate, margins entire. Hypanthium obconical, 1.7-2.7 mm long, smooth, fused to the ovary except distally. Sepals simple, deltate, crescent-shaped or semi-orbicular, $0.4-1.1 \times 0.8-1.4 \mathrm{~mm}$, thick, apex acute to acuminate, rarely obtuse, margins entire or denticulate. Corolla up to $5.5 \mathrm{~mm}$ across; petals white, orbicular, 1.6-3.0 $\times 1.6-2.7 \mathrm{~mm}$, oil glands present, margins entire. Stamens 8-12, in groups of 1-3 opposite sepals, stamen opposite calyx-lobe shorter than remainder; filaments c. $0.8 \mathrm{~mm}$ long, not glandular; anthers versatile, c. $0.3 \mathrm{~mm}$ long, connective gland brown, c. 0.25 times as long as anther cells. Style terete, $0.7-1.2 \mathrm{~mm}$ long at anthesis, stigma broadly capitate. Ovary 2-locular, roof of ovary concave, ovules 11-15 per loculus, arranged in two separated longitudinal rows or somewhat radially arranged around placenta. Fruit ovoid-cylindric to campanulate, $1.7-2.0 \times 2.0-2.5 \mathrm{~mm}$, valves inconspicuous. Seeds c. $0.6 \mathrm{~mm}$ long, pale brown.

Distribution and habitat: Baeckea linifolia extends from Springbrook and Binna Burra in the extreme south of Queensland, throughout eastern New South Wales, to eastern Victoria (Fig. 2). It often grows along creek-banks in sheltered forested sites, but it also grows in open heathland on hillsides on relatively xeric sites.

Phenology: flowering occurs from December-June; fruiting from March-December.

Affinities: B. linifolia is closely related to B. frutescens, but differs by its consistently 2-locular ovary, acute sepals, larger petals and leaves borne singly at each node.

Conservation status: B. linifolia is a common and widespread species.

Note: there is much variation in the leaf length of B. linifolia, and the shorter-leaved material has been separated as B. linifolia var. brevifolia, particularly in Victoria. 
However, short-leaved material can occur throughout the range of B. linifolia, and appears to be correlated to the habitat in which the plants are growing. Plants growing in relatively xeric sites in heathland may have quite short leaves, while nearby plants growing on creek-banks or in sheltered gullies may have long leaves.

Selected specimens: Queensland: Moreton: Daves Creek circuit, Lamington N.P., Forster PIF15972 E Leiper, 27 Dec 1994 (BRI, MEL, NSW); Springbrook, SW of Mudgeeraba, Bean 7310, 16 Jan 1994 (AD, BRI, NSW); Springbrook, White 6220, Sep 1929 (A).

New South Wales: North Coast: along Boogarem Ck, above falls, Nullum S.F., Floyd AGF1284, 26 June 1979 (NSW); Koonyum Range, west of Mullumbimby, Bean 6183, 17 July 1993 (BRI, CANB, MEL, NSW); Rocky Creek, Whian Whian S.F., N of Lismore, Bean 7967, 15 Oct 1994 (BRI). Central Coast: Northbridge, Sydney, Helms 734, 9 Apr 1922 (A); top of Bulli Pass, 35 miles S of Sydney, Rodway 1746, 12 May 1935 (A, K). Central Tablelands: Newnes S.F., 2.4 km NNE of Forestry Hut, Benson 1243 et al., 22 May 1978 (NSW); Braeside Walk, Blackheath, Blue Mtns, Collier 3181, 15 May 1988 (HO); Bridal Veil falls, Wentworth Falls, Constable s.n., 31 Dec 1959 (A, NSW); Maddens Plain, 2 km NE of Sublime Point, Coveny 11107 \& Taylor, June 1982 (A, K, NSW). South Coast: Mt Currockbilly, 50 miles SW of Nowra, Rodway 3072, Jan 1940 (A); 4.5 km ENE of Mt Tianjara, Adams \& Paijmans 3825, 26 Mar 1981 (CANB); Nadgee Nature Reserve, junction of service track and track to Mt Nadgee trig., Parris 9843,9 Dec 1977 (CANB, NSW). Southern Tablelands: Corang Trig station, northern Budawang Range, Olsen s.n., 15 Feb 1969 (NSW).

Victoria: East Gippsland: 0.5 miles NE of Maramingo Creek, near Genoa, Melville 2711 \& Wakefield, 7 Jan 1953 (K, MEL, NSW); c. 4 km WNW of Mallacoota, Clarke 1919, 21 Feb 1989 (BRI, CANB, MEL, NSW); 0.6 km along Pipeline track, Mallacoota, Jobson 4161, Mar 1996 (BRI, CANB, MEL, NSW).

3. Baeckea leptocaulis Hook. f., Icon. Pl. 3: t. 298 (1840).

Type: Tasmania: Rocky Cape, R.C. Gunn 817/1842, 22 February 1838 (holo BM; iso: HO, NSW).

Shrub $0.3-1 \mathrm{~m}$ high, or rarely to $2.5 \mathrm{~m}$. Bark shedding in papery layers. Branchlets grey or brown, segments flat, not flanged, margins entire; oil glands absent. Leaves solitary at each node, linear, straight, plano-convex to concavo-convex, not keeled, 4.5-10.0(-12.5) mm long, 0.8-1.2 mm wide, oil glands visible on both surfaces, midvein not visible, margins entire, apex acute, base cuneate; petioles $0.8-1.4 \mathrm{~mm}$ long. Peduncles c. $0.5 \mathrm{~mm}$ long; pedicels $1.5-3.5 \mathrm{~mm}$ long, bracteoles linear, c. $2.5 \mathrm{~mm}$ long, caducous before anthesis, acuminate, margins entire. Hypanthium obconical, $1.6-2.6 \mathrm{~mm}$ long, smooth, fused to the ovary except distally. Sepals simple, oblong to deltate, c. $0.8 \times 0.9 \mathrm{~mm}$, thick, apex obtuse, margins entire. Corolla up to $6 \mathrm{~mm}$ across; petals white, orbicular, 1.6-2.2 × 2.0-2.5 mm, oil glands present though rather obscure, margins entire. Stamens 5 or 6 , very rarely 7, scattered, but not opposite petals, all about same length; filaments c. $0.7 \mathrm{~mm}$ long, not glandular; anthers versatile, c. $0.3 \mathrm{~mm}$ long, connective gland brown, c. a quarter as long as anther cells. Style terete, c. $1.0 \mathrm{~mm}$ long at anthesis, stigma broadly capitate. Ovary 2-locular, roof of ovary concave, ovules 8-11 per loculus, arranged in two longitudinal rows on placenta. Fruit cylindrical to campanulate, $2.0-2.8 \times 2.0-2.8 \mathrm{~mm}$ in diameter, valves inconspicuous. Seeds c. $1.1 \mathrm{~mm}$ long, pale brown.

Distribution and habitat: Baeckea leptocaulis is endemic to Tasmania, where it is widespread throughout the western one-third of the island (Fig. 3), at altitudes from 20-900 metres. It grows in wet heathland with species such as Restio complanatus R.Br., Sprengelia incarnata Sm., Bauera rubioides Andrews, Gymnoschoenus sphaerocephalus (R.Br.) Hook. f. (Button grass) and Epacris spp.

Phenology: B. leptocaulis flowers between December and March, and bears fruits between March and November.

Affinities: $B$. leptocaulis is closely related to B. linifolia, but differs by having 5 or $6(-7)$ stamens per flower (8-12 for linifolia), obtuse sepals (mostly acute or acuminate for 
linifolia), 8-11 ovules per loculus (11-15 for linifolia), and rathery papery bark (scaly for linifolia).

Conservation status: B. leptocaulis is a common and widespread species.

Selected specimens: Tasmania: North West: Horton River, Moscal 7589, 13 Apr 1984 (BISH, HO, MEL). South West: near Hibbs Lagoon, Buchanan 1850, 7 Dec 1983 (HO); north side of Mt Gaffney, Buttermore 58, 14 Jan 1986 (HO); Middle Giblin River basin, 8 km NW of Mt Gaffney, $13 \mathrm{~km} \mathrm{~N}$ of Mulcahy Bay, Croft 10144 \& Richardson, 17 Feb 1989 (CANB, HO, MEL, NSW); 1.5 km N of Elliot Bay, Moscal 9871, 1 Mar 1985 (BRI, HO, NSW); north-west slopes of Sentinel Range, Moscal 10958, 25 May 1985 (AD, HO, MEL); Port Davey, Hubble s.n., 15 Feb 1948 (HO); Wart Hill, Moscal 9847, 28 Feb 1985 (BRI, CANB, HO); between Deadmans Bay and Lousy Bay, Buchanan 9613, 19 Jan 1987 (HO); foot of Moraine A, Western Arthur Range, Collier 1979, 7 Dec 1986 (HO); S end of Moinee Ridge, Cox Bight, Orchard 5785, 31 Dec 1982 (HO, MEL). West Coast: Burgess Creek, Buchanan 11665, 26 Jan 1990 (HO); Gordon Plains, Collier 1233, 16 Feb 1986 (HO); 9 km N from Balfour, Davies 1156 et al., 22 Jan 1989 (CANB, HO, MEL); Lake Curly, Jarman s.n., 8 Feb 1985 (HO); slopes of Mt Wright, Gordon s.n., 15 Dec 1942 (HO); Mt Balfour, Moscal 4921, 17 Dec 1983 (CANB, HO); Lindsay River, Moscal 5083, 20 Dec 1983 (CANB, HO, NSW); Forked Tree Hill, Dempster Plains, Moscal 7626, 14 Apr 1984 (BM, HO); 5 km S of Neasey Plains, Moscal 7265, 30 Mar 1984 (CANB, HO); 1 km NE of Strahan, Moscal 5279, 6 Jan 1984 (HO).

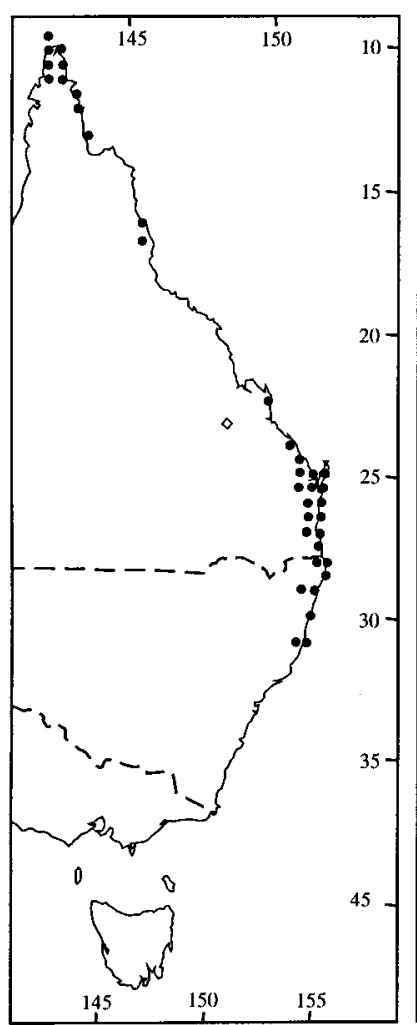

Fig. 1.

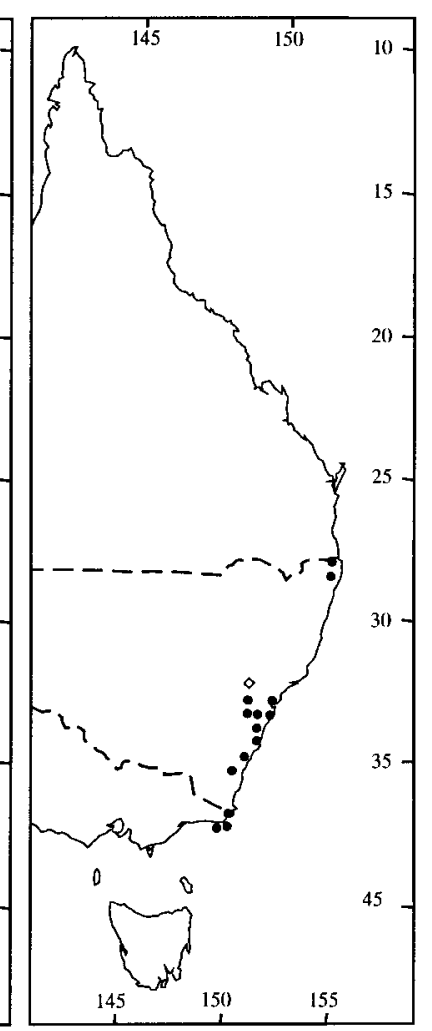

Fig. 2.

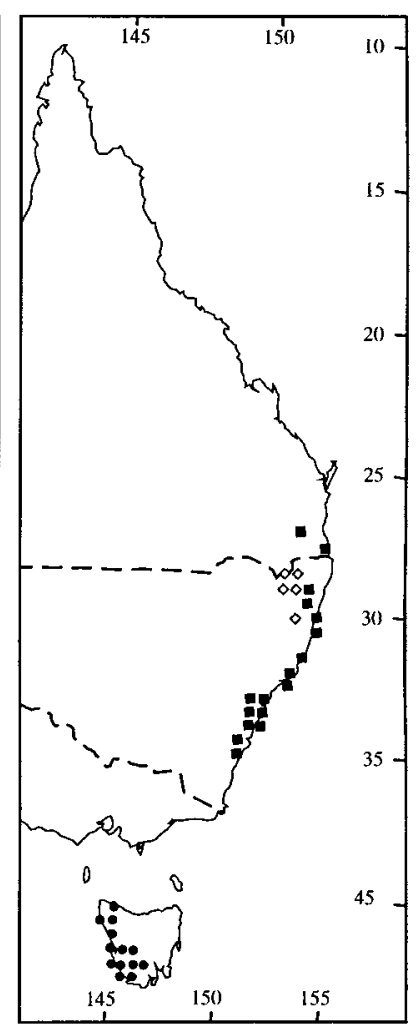

Fig. 3.

Fig. 1. Distribution of Baeckea frutescens $₫ ;$ Baeckea trapeza $\diamond$

Fig. 2. Distribution of Baeckea linifolia $₫ ;$ Baeckea kandos $\diamond$

Fig. 3. Distribution of Baeckea omissa $\diamond$; Baeckea leptocaulis $₫$; Baeckea diosmifolia $₫$ 
4. Baeckea imbricata (Gaertn.) Druce, Bot. Soc. Exch. Club Brit. Isles. supp. 2: 608 (1917).

Jungia imbricata Gaertn., Fruct. Sem. Pl. 1: 175 (1788); Mollia imbricata (Gaertn.) J.F. Gmel., Syst. Nat.: 420 (1791); Imbricaria crenulata Sm., Trans. Linn. Soc. London 3: 259 (1797), nom. illeg.; Stereoxylon crenulata (Sm.) Poir., Encycl., Suppl. 5: 247 (1817); Escallonia crenulata (Sm.) Schult., Syst. Veg. 5: 329 (1819); Baeckea crenulata (Sm.) DC., Prodr. 3: 230 (1828); Schidiomyrtus crenulata (Sm.) Schauer, Linnaea 17: 237 (1843).

Type: New South Wales: Botany Bay, J. Banks \& D. Solander s.n., April-May 1770 (holo BM n.v., photo BRI).

Jungia tenella Gaertn., Fruct. Sem. Pl. 1: 176 (1788); Schidiomyrtus tenella (Gaertn.) Schauer, Linnaea 17: 237 (1843); Baeckea crenulata var. tenella (Gaertn.) Benth., Fl. Austral. 3: 78 (1867); Baeckea imbricata var. tenella (Gaertn.) Hochr., Candollea 2: 467 (1925); Baeckea imbricata var. typica Domin, Biblioth. Bot. 89: 450 (1928), nom. inval.

Type: New South Wales: Botany Bay, J. Banks \& D. Solander No. 53, April-May 1770 (holo BM).

Baeckea diosmoides Sieber ex DC., Prodr. 3: 230 (1828); Schidiomyrtus sieberi Schauer, Linnaea 17: 237 (1843), nom. illeg.

Type: Nov. Holl., F.W. Sieber 277, 1823, (holo G-DC, microfiche BRI; iso GH).

Shrub to $0.6 \mathrm{~m}$ high, rarely to $1.5 \mathrm{~m}$ high. Bark grey, scaly. Branchlets grey, segments flat to convex, slightly to conspicuously flanged, margins entire; oil glands absent. Leaves solitary at each node, elliptical, broadly ovate or orbicular, straight, flat, not keeled, 2.4-5.4(8.0) mm long, 2.0-3.9(6.7) $\mathrm{mm}$ wide, oil glands obscure on both surfaces, midvein not or faintly visible, margins entire or denticulate in upper half of leaf, apex obtuse or acute, base cuneate, obtuse or cordate; petioles absent or up to $0.3 \mathrm{~mm}$ long. Peduncles absent or up to $0.4 \mathrm{~mm}$ long; pedicels $0.3-0.8(1.2) \mathrm{mm}$ long, bracteoles lanceolate, 1.5-2.5(3.5) $\mathrm{mm}$ long, often persistent to anthesis, apex acute to acuminate, margins entire. Hypanthium obconical, 1.5-2.5(3.0) $\mathrm{mm}$ long, smooth or faintly ribbed, fused to the ovary except distally. Sepals simple, oblong, 0.7-1.2(1.8) $\times$ 0.8-1.2(1.8) $\mathrm{mm}$, thin, apex obtuse, margins entire or denticulate. Corolla up to $4.5 \mathrm{~mm}$ across; petals white, orbicular, 1.4-1.6(2.4) $\times 1.4-1.9(2.8) \mathrm{mm}$, oil glands present, margins entire. Stamens $5-12$, in groups of 1-3 opposite the sepals, stamen opposite sepal shorter than remainder; filaments c. $0.7 \mathrm{~mm}$ long, glandular; anthers versatile, c. $0.3 \mathrm{~mm}$ long, connective gland brown, less than one-quarter as long as anther cells. Style terete, c. $1.0 \mathrm{~mm}$ long at anthesis, stigma slightly capitate. Ovary 2-locular, roof of ovary concave, ovules 3-4 or 9-10 per loculus, arranged in two longitudinal rows on placenta. Fruit ovoid-cylindric, c. $2.0 \mathrm{~mm}$ long and $1.5 \mathrm{~mm}$ in diameter, valves inconspicuous. Seeds not seen.

Distribution and habitat: Baeckea imbricata inhabits coastal lowland areas from Cooloola National Park (26 $\left.04^{\prime}\right)$ in Queensland to Bawley Point (35 31') in New South Wales. There is also a single record from Tasmania (see notes below) (Fig. 6). B. imbricata grows in coastal heathy swamps dominated by Epacris or Leptospermum spp., and in low open eucalypt woodland with heathy understorey. In New South Wales, it also extends inland to the tablelands, on sandy soil over sandstone.

Phenology: flowering occurs from November-April, with one record in August; fruiting occurs from February to May.

Notes: there appears to be discontinuous variation in B. imbricata, based on the number of stamens and ovules in the flowers. Bean 8009 (Evans Head) and Blake 13175 (Stradbroke Island) have 8-12 stamens per flower and 9 or 10 ovules per loculus. Bean 5782, 8122, 8154 (Peregian, Cooloola, Kin Kin) and Whalen 2 \& Coveny (Oxford Falls) have 5-8 stamens per flower and 3 or 4 ovules per loculus. As these differences do not 
appear to correlate with other morphological characters or geography, no taxonomic status has been given to these variants.

A single plant of B. imbricata was found in bushland in eastern Tasmania by John and Marion Simmons. Cuttings were taken, and the plant was grown on, and a specimen was taken from the cultivated plant and lodged at $\mathrm{HO}$ (cited above). The original plant was destroyed by fire and no plants have yet been relocated in the area (M. Simmons pers. comm.).

Conservation status: $B$. imbricata is a common and widespread species

Selected specimens: Queensland: Wide Bay: Cooloola N.P., 2 km SW of Noosa River bridge, Bean 8122, 26 Nov 1994 (BRI, HO, MEL, NSW); Yalanga station, Bates Road, NE of Kin Kin, Bean 8154 E Grimshaw, 29 Dec 1994 (BRI). Moreton: Coolum, Blake 19086, 5 Nov 1952 (BRI, NSW); near Dunwich, Stradbroke Island, Blake 13175, 10 Jan 1938 (BRI, CANB, K, NSW); Tugun, Clemens 42699, Sep 1943 (A).

New South Wales: North Coast: Chinaman's Beach, just S of Evans Head, Bean 8009, 12 Nov 1994 (A, BRI, MEL, NSW); Red Rock, 25 miles [40 km] SE of Grafton, Constable 4911, 28 May 1964 (NSW); Crowdy Bay N.P., D'Aubert 263 \& Kocur, 20 Apr 1988 (NSW). Central Coast: Kurnell, Botany Bay, Boorman, May 1911 (NSW); NW end of Uloola track, Royal N.P., Davies 394 \& Mulcahy, 6 Dec 1987 (CANB, NSW); 0.5 miles [0.8 km] W of Bulli Pass Lookout, McBarron 14100, 27 Mar 1967 (NSW); Bass Point, Shellharbour, Rodd s.n., 11 June 1981 (NSW); Fairfax Walk, North Head, Sydney Harbour N.P., Hind 5922 \& Cadogan, 4 Sep 1989 (NSW); N of Oxford Falls road, near junction with Spicer road, Oxford Falls, c. 2.5 km NE of Frenchs Forest, Whalen 2 \& Coveny, 19 Feb 1993 (BRI, CANB, HO, MEL, NSW). Central Tablelands: Hazelbrook, Hamilton, Jan 1915 (NSW); Woodford, Maiden s.n., Jan 1899 (NSW). South Coast: bay N of Bawley Point, Walker ANU1367, Nov 1964 (CANB, NSW). Southern Tablelands: Budawang Range, c. 9 km S of Sassafras, Austin \& Duggan 45, 9 Dec 1972 (CANB, NSW); 12.9 km ESE of Nerriga, Pickard 1712, Sep 1971 (NSW).

Cultivated: Tasmania: Legana (ex Sloop Rock, N of St Helens), Simmons \& Simmons, June 1988 (HO).

5. Baeckea diosmifolia Rudge, Trans. Linn. Soc. London 8: 298 (1807).

Type: New Holland, collector unknown, undated (holo BM n.v., photo BRI).

Schidiomyrtus diosmifolia (Rudge) Schauer, Linnaea 17: 237 (1843).

Shrub to $0.6 \mathrm{~m}$ high. Bark grey, fibrous. Branchlets white to brown, segments flat to convex, slightly flanged, margins entire; oil glands present. Leaves solitary at each node, oblanceolate, curved, plano-convex to concavo-convex, not keeled, 2.1-4.5 mm long, 0.5-1.5 mm wide, oil glands prominent on both surfaces, midvein not visible, margins denticulate, apex obtuse, base cuneate; petioles c. $0.2 \mathrm{~mm}$ long. Peduncles absent or up to $0.3 \mathrm{~mm}$ long; pedicels absent or up to $0.5 \mathrm{~mm}$ long, bracteoles linear to lanceolate, 1.2-2.8 $\mathrm{mm}$ long, persistent to anthesis, apex obtuse or acute, margins ciliate. Hypanthium obconical, 1.7-2.4 mm long, smooth, fused to the ovary except distally. Sepals simple, semi-orbicular, $0.5-1.0 \times 0.9-1.3 \mathrm{~mm}$, thin, apex obtuse, margins denticulate. Corolla up to $5.5 \mathrm{~mm}$ across; petals white, orbicular, $1.2-1.8 \times 1.3-1.8 \mathrm{~mm}$, oil glands present, margins entire. Stamens 7-9, scattered, but not opposite the petals, stamens all about same length; filaments c. $0.7 \mathrm{~mm}$ long, glandular; anthers versatile, c. $0.3 \mathrm{~mm}$ long, connective gland brown, c. one-quarter as long as anther cells. Style terete, c. $1.0 \mathrm{~mm}$ long at anthesis, stigma slightly capitate. Ovary 2-locular, roof of ovary concave, ovules 7-11 per loculus, arranged in two longitudinal rows on placenta. Fruit obconical to ovoid-cylindric, c. $2.2 \mathrm{~mm}$ long and c. $2.0 \mathrm{~mm}$ in diameter, valves inconspicuous. Seeds c. $0.5 \mathrm{~mm}$ long, yellow to brown.

Distribution and habitat: Baeckea diosmifolia was recorded from Miami (Gold Coast) in the 1950s, and from Rochedale and Springwood (suburbs of Brisbane) in the 1970s, but these populations are now believed to be extinct. 
It is currently known from one population in Queensland (Crows Nest), but occurs in numerous localities in New South Wales (Fig. 3). It grows most often in open eucalypt woodland with heathy understorey, on lower slopes in hilly areas with quartzose sandstone, but also on coastal heathland.

Phenology: flowers are recorded from December to May; fruits from April to October.

Conservation status: B. diosmifolia is rare in Queensland, but it is widespread and common in New South Wales. Hence no conservation coding is suggested for it.

Selected specimens: Queensland: Moreton: Hartmann Park, Crows Nest, Bean 8407, 16 Mar 1995 (A, BRI, L, MEL, NSW); Ford road, Rochedale, Thomas s.n., 14 Apr 1972 (BRI); Miami, Thorne 20451 E Blake, Apr 1959 (CANB); Springwood, Olsen \& Lebler 824, 10 May 1979 (BRI).

New South Wales: North Coast: Rocky Creek, 28 km from Grafton towards Coaldale, Bean 8347, 3 Feb 1995 (BRI, NSW); Wallis Island, Tuncurry, Cheel, 11 May 1925 (NSW); South West Rocks near oil storage tanks, Coveny 12221 \& Bishop, 16 Apr 1986 (NSW); 3 miles [5 km] S of Nelson Bay, Filson 3572, Dec 1960 (MEL); Bonny Hills to North Haven, Salasoo 4735, 8 Jan 1971 (NSW). Central Coast: Parramatta, Caley s.n., Dec 1800 (A); Narrabeen, Day s.n., Aug 1936 (CANB); Royal N.P., NW end of Uloola track, Davies 404 \& Mulcahy, 6 Dec 1987 (CANB, NSW); Hawkesbury sandstone near Woy Woy, Francis s.n., Dec 1914 (A); end of Irwins Road, Bull's Ridge, East Kurrajong, James 1187, 20 Mar 1990 (NSW); Picton lakes, Thirlmere, McBarron 18956, 26 Dec 1969 (NSW); Sydney, Wright s.n., 1853-6 (GH). Central Tablelands: c. 4 km direct NW from Penrose station, E branch of Hanging Rock Swamp, Berentson 3 \& Davies, 11 Jan 1995 (CANB). South Coast: 6 km WSW of Mt Tianjara, Adams \& Paijmans 3721, 2 Mar 1981 (CANB); Milton, Cambage s.n., Dec 1902 (GH); Northern Budawang Range, Folly Point, Telford 10168, 11 Jan 1986 (CANB, MEL, NSW).

Intermediate forms: the distinction between $B$. diosmifolia and B. imbricata is blurred by the occurrence of intermediate forms in some parts of New South Wales. Some of these may be accounted for by the not often recognised juvenile leaf form of $B$. imbricata, which is much narrower than the adult form and mimics B. diosmifolia to some degree. However it is still probable that hybrids or intergrades between $B$. diosmifolia and $B$. imbricata exist, particularly at the southern end of their distributions, exemplified by a series of collections by J. Pickard from $12.9 \mathrm{~km}$ ESE of Nerriga. These appear to range from typical B. imbricata to almost typical B. diosmifolia. The true situation will only be determined by careful field study.

Intermediates $(B$. diosmifolia $\times$ B. imbricata)

New South Wales: Central Tablelands: ridge west of Carrington Falls, Abell 91, 15 Aug 1985 (NSW). Southern Tablelands: Currockbilly, Boorman, Feb 1910 (BRI, NSW); 12.9 km ESE of Nerriga, Pickard 1316,1323, 27 Dec 1970 (NSW); 12.9 km ESE of Nerriga, Pickard 1698, 6 Apr 1971 (NSW); 10 km NW of Milton, Adams \& Paijmans 3732, 25 Mar 1981 (CANB, NSW).

\section{Baeckea trapeza A.R. Bean, sp. nov.}

B. diosmifoliae affinis sed stipitibus $1-1.5 \mathrm{~mm}$ longis, marginibus foliorum integris ovulis 14-15 in quoque loculo differens.

Typus: Queensland: Two Mile Creek, Blackdown Tableland, SE of Blackwater, $23^{\circ} 45^{\prime} \mathrm{S}$ 14906'E, A.R. Bean 9624, 27 January 1996 (holo BRI; iso HO, K, MEL, NSW, PERTH).

Baeckea sp. (Blackdown Tableland C.H. Gittins 938) in Bean (1997b)

Shrub to $1 \mathrm{~m}$ high. Bark grey, scaly, persistent. Branchlets grey to brown, segments flat, not flanged, margins entire; oil glands present or absent. Leaves solitary at each node, oblanceolate, straight or slightly recurved, plano-convex to concavo-convex, not keeled, 3.0-4.5 mm long, 0.6-1.2 mm wide, oil glands visible on both surfaces, scattered, midvein not visible, margins entire, apex obtuse, base cuneate; petioles c. $0.4 \mathrm{~mm}$ long. Peduncles c. $0.4 \mathrm{~mm}$ long; pedicels $1.0-1.5 \mathrm{~mm}$ long, bracteoles linear, 1.3-2.0 mm long, caducous before anthesis, apex acute, margins entire. Hypanthium 
obconical, 2.0-2.5 mm long, smooth, fused to the ovary except distally. Sepals simple, semi-orbicular, c. $0.4 \times 1.0 \mathrm{~mm}$, thick, apex obtuse, margins entire or denticulate. Corolla up to $5.5 \mathrm{~mm}$ across; petals white, orbicular, $1.4-1.8 \times 1.4-1.7 \mathrm{~mm}$, oil glands present, margins entire. Stamens $8-11$, in groups of 1-3 opposite the sepals, all about same length; filaments $0.4-0.8 \mathrm{~mm}$ long, not glandular; anthers versatile, c. $0.3 \mathrm{~mm}$ long, connective gland brown, one-third to one-half as long as anther cells. Style terete, c. $0.7 \mathrm{~mm}$ long at anthesis, stigma broadly capitate. Ovary 2-locular, roof of ovary concave, ovules 14 or 15 per loculus, arranged in two longitudinal rows on placenta. Fruit obconical to campanulate, $2.5-3.0 \times 2.2-2.5 \mathrm{~mm}$, valves inconspicuous. Seeds not seen. Fig. 4 a-c.

Distribution and habitat: Baeckea trapeza is confined to the Blackdown Tableland, west of Rockhampton in central Queensland (Fig. 1). It grows at altitudes around 700-800 metres. Some associated species are Leptospermum polygalifolium Salisb., Triplarina paludosa A.R. Bean and Melastoma affine D. Don.

Phenology: flowers have been recorded for January and April; fruits in September and November.

Affinities: $B$. trapeza has been known for some years as $B$. sp. aff. diosmifolia. It differs from $B$. diosmifolia by its leaves with entire margins, pedicels $1-1.5 \mathrm{~mm}$ long, shorter sepals and 14-15 ovules per loculus. It is also closely related to B. omissa (see notes under that species).

Conservation status: the risk category for Baeckea trapeza according to the criteria of Chalson \& Keith (1995) is 'endangered' (criteria B1, B2, D). The risk category according to the IUCN system is 'vulnerable' (criteria B1,D1,D2). It is known only along the banks of two creeks on Blackdown Tableland (South Mimosa Creek and Two Mile Creek) and the total population is estimated at 500 plants. The recommended conservation status for this species as defined by the Queensland Nature Conservation Act 1992 is 'vulnerable'.

Etymology: the specific epithet is from the Greek word trapeza, an indeclinable noun in apposition, meaning 'a table'. This is in reference to the location of the species on Blackdown Tableland.

Specimens examined: Queensland: Leichhardt: south branch of Mimosa Creek, Blackdown Tableland, Bean 6948, 16 Nov 1993 (BRI, MEL); Blackdown Tableland, 1st creek, Gittins 938, Sep 1964 (BRI); Blackdown Tableland, c. $32 \mathrm{~km}$ SE of Blackwater, Henderson H643 et al., 18 Apr 1971 (BRI); Two Mile Creek, Blackdown Tableland, 12 miles [19 km] SSE of Bluff, Johnson 987, 20 Sep 1959 (BRI); Blackdown Tableland, Two Mile Ck, adjacent to walking track to Two Mile Falls, Sparshott KMS541 E Sparshott, 14 Apr 1995 (BRI); Blackdown Tableland, South Mimosa Creek, Telford 5750, June 1977 (CANB).

\section{Baeckea omissa A.R. Bean, sp. nov.}

B. trapezae affinis sed foliis fructibusque brevioribus, hypanthiis $1.2-2 \mathrm{~mm}$ longis, ovulis 11 vel 12 in quoque loculo differens.

Typus: New South Wales: Forest Land State Forest, $25 \mathrm{~km}$ SSE of Tenterfield, $29^{\circ} 13^{\prime} \mathrm{S}$ 152 07'S, A.R. Bean 7253, 31 December 1993 (holo BRI; iso AD, DNA, MEL, NSW).

Baeckea sp. 1, Stanley \& Ross, Flora of S.E. Queensl. 2: 125 (1986).

Baeckea sp. C, Wilson in Harden (ed.), Flora of N.S.W. 2: 184-5 (1991).

Baeckea sp. (Racecourse Creek L.S. Smith 775) in Bean (1997b).

Shrub usually to $0.6 \mathrm{~m}$, but up to $2.5 \mathrm{~m}$ high. Bark grey, closely fibrous. Branchlets white to grey, segments flat, not flanged, margins entire; oil glands present. Leaves solitary at each node, obovate to oblanceolate, straight, concavo-convex, not keeled, 

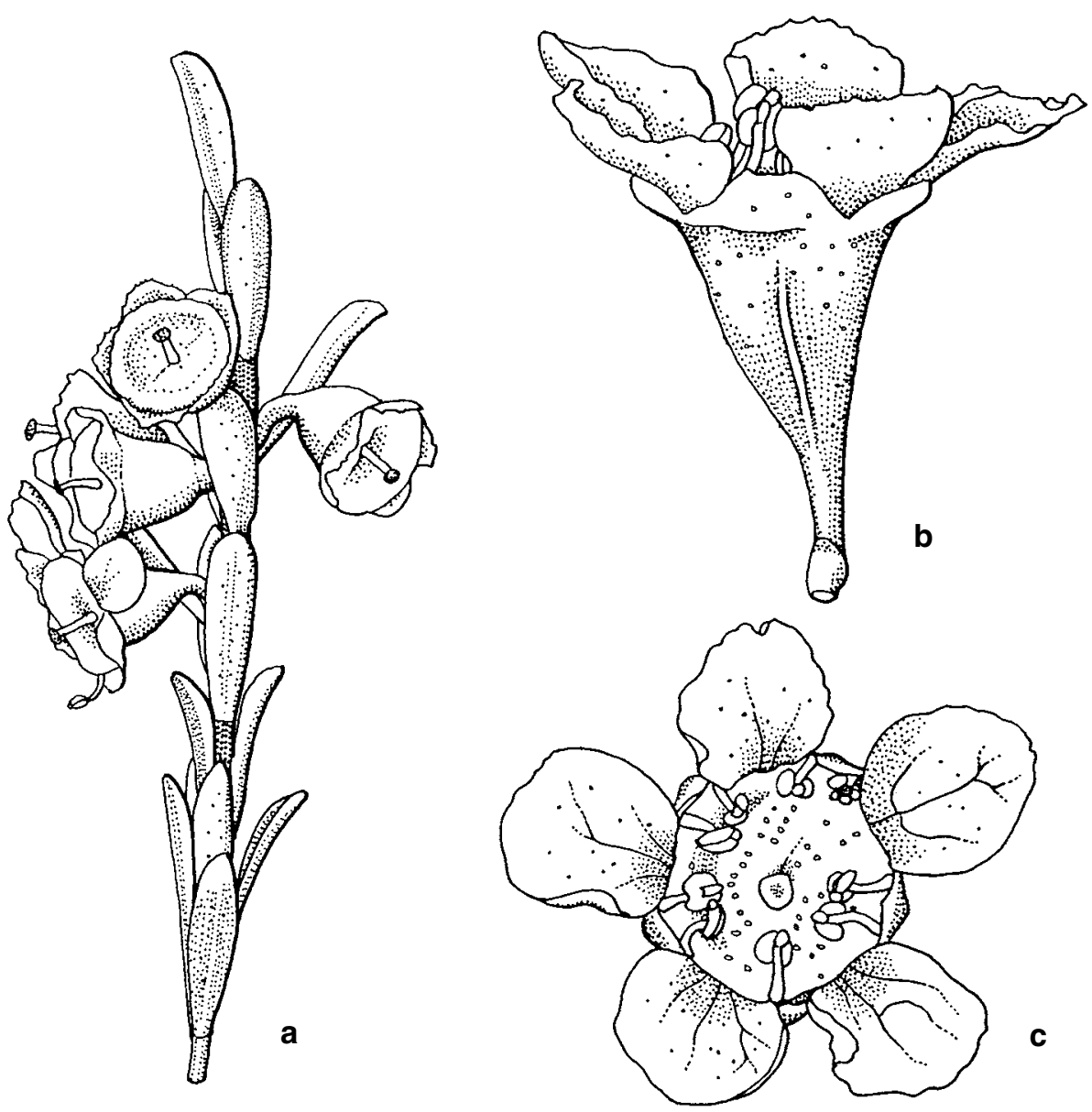

Fig. 4. Baeckea trapeza. $\mathbf{a}$, flowering branchlet $(\times 6)$; $\mathbf{b}$, hypanthium and sepals $(\times 12)$; $\mathbf{c}$, petals and stamens $(\times 12)$. a-c from holotype.

2.0-3.3 mm long, 0.5-1.2 mm wide, oil glands prominent on both surfaces, midvein not visible, margins entire or obscurely denticulate on apical half of leaf, apex acute, base cuneate; petioles c. $0.3 \mathrm{~mm}$ long. Peduncles c. $0.3 \mathrm{~mm}$ long; pedicels $0.8-1.6 \mathrm{~mm}$ long, bracteoles linear, 1.8-2.0 mm long, caducous before anthesis, apex acute to acuminate, margins mostly entire. Hypanthium obconical, 1.2-2.0 mm long, smooth, fused to the ovary except distally. Sepals simple, semi-orbicular, 0.5-0.6 $\times 0.5-1.0 \mathrm{~mm}$, thick, apex obtuse, margins entire or denticulate. Corolla up to $7 \mathrm{~mm}$ across; petals white, orbicular, $1.5-2.5 \times 1.5-2.0 \mathrm{~mm}$, oil glands present, margins entire. Stamens $8-10$, in groups of 1-3 opposite the sepals, stamens all about same length; filaments c. $0.8 \mathrm{~mm}$ long, glandular; anthers versatile, c. $0.3 \mathrm{~mm}$ long, connective gland yellow or brown, c. one-quarter to half as long as anther cells. Style terete, c. $0.7 \mathrm{~mm}$ long at anthesis, stigma broadly capitate. Ovary 2-locular, roof of ovary concave, ovules 11-12 per loculus, arranged in two longitudinal rows on placenta. Fruit hemispherical, c. $1.5 \mathrm{~mm}$ long and $2.2 \mathrm{~mm}$ in diameter, valves inconspicuous. Seeds not seen. Fig. $4 \mathrm{~d}-\mathrm{f}$.

Distribution and habitat: Baeckea omissa occurs in the Stanthorpe area of Queensland, and is widespread on the New England Tableland of northern New South Wales (Fig. 3). 
It grows in treeless heathy swamps in association with, for example, Leptospermum gregarium Joy Thomps., Callistemon pityoides F. Muell. and Hydrocotyle spp.

Phenology: flowers have been recorded from October-February; fruits from March-September.

Affinities: $B$. omissa is most closely related to B. trapeza. B. omissa differs by its leaves 1.8-3.3 mm long (3.3-4.5 mm long for trapeza), hypanthium 1.2-2 mm long (2-2.5 mm for trapeza), shorter fruits and 11-12 ovules per loculus (14-15 for trapeza). It is also close to B. gunniana, differing by the greater numer of stamens, the shorter sepals and the 2-locular ovary.

Conservation status: $B$. omissa is a common and widespread species

Etymology: the specific epithet is from the Latin omissus, meaning 'neglected or overlooked', and refers to the late recognition of this taxon as a separate species.

Note: there is a collection of B. omissa at NSW, bearing the location Hill Top (southwest of Sydney), and collected by J.H. Maiden. As this locality is so far from the known range of the species, and no other collector has recorded it at or near this place, it must be regarded as a dubious record. Maiden frequently collected on the New England Tableland (Peter Wilson, pers. comm.), and it seems likely that the specimen in question has been incorrectly labelled.

Specimens examined: Queensland: Darling Downs: South Bald Rock swamp, northern end, Girraween N.P., Grimshaw G416 \& Robins, 2 Feb 1994 (BRI); Racecourse Creek, NE of Wallangarra, Smith 775, 29 Jan 1940 (A, BRI).

New South Wales: Northern Tablelands: Bark Hut swamp, Boonoo Boonoo S.F., NNE of Tenterfield, Bean 7249, 31 Dec 1993 (BRI, NSW); Silent Grove-Torrington road, $10.5 \mathrm{~km} \mathrm{~N}$ of Torrington, Bean 8258, 28 Jan 1995 (BRI, NSW); Pheasant Creek, Glen Elgin, c. 30 miles [48 km] NE of Glen Innes, Boorman, Dec 1913 (NSW); Casino S.F., 43 miles [69 km] east of Glen Innes, Constable, May 1961 (NSW); c. 2 km NW of Round Mountain, Hunter 2570 et al., 21 Jan 1995 (NE, NSW); 'Lyrebird track', New England N.P., Sparshott KMS322 \& Sparshott, 18 Sep 1994 (BRI, CANB, NSW); Mount Lindsay Hwy, $1.8 \mathrm{~km} \mathrm{~S}$ of Stanthorpe turnoff, Wilson $1317 \mathcal{E}$ Rowe, 20 Jan 1992 (NSW); c. 7 miles [11 km] NW of Ebor, on Guyra road, Vickery, Oct 1958 (NSW); Armidale, Welch, Aug 1936 (NSW).

8. Baeckea gunniana Schauer in Walp., Repert. Bot. Syst. 2: 920 (1843).

Type: Tasmania: 'Van Diemens Land', Mt Wellington, R.C. Gunn 306/1842, 31 January 1840 or 9 February 1839 (lecto K (here chosen), the large specimen in bottom left corner).

Tetrapora gunniana (Schauer) Miq., Ned. Kruidk. Arch. 4: 150 (1856).

Baeckea micrantha Hook.f., Icon. Pl. 3: t. 309 (1840), nom. illeg., non DC. (1828).

Types: Tasmania: 'Van Diemens Land', May-day Plain, Black Bluff, Vale of Belvoir, R.C. Gunn 815/1837, February 1837 (syn K).

Illustration: G.R. Cochrane, Fl. \& Plants of Victoria \& Tasmania: 105 (1980).

Shrub to $1.5 \mathrm{~m}$ high. Bark brown, papery or fibrous. Branchlets brown, segments flat, not flanged, margins entire; oil glands present. Leaves solitary at each node, elliptical to obovate, straight, plano-convex to concavo-convex, not keeled, 1.9-3.8 $\mathrm{mm}$ long, 0.9-1.4 mm wide, oil glands visible on both surfaces, midvein not visible, margins entire, apex acute or obtuse, base cuneate; petioles c. $0.5 \mathrm{~mm}$ long. Peduncles absent; pedicels $0.4-1.0 \mathrm{~mm}$ long, bracteoles linear, c. $1 \mathrm{~mm}$ long, caducous before anthesis, apex acute, margins entire. Hypanthium obconical, 1.9-2.4 $\mathrm{mm}$ long, smooth, fused to the ovary except distally. Sepals simple, oblong, 0.6-0.8 $\times 0.9-1.1 \mathrm{~mm}$, thin, apex obtuse, margins entire. Corolla up to $5 \mathrm{~mm}$ across; petals white, orbicular, $1.5-1.8 \times$ 1.5-2.0 mm, oil glands absent, margins entire. Stamens $4-6$, scattered but not opposite 

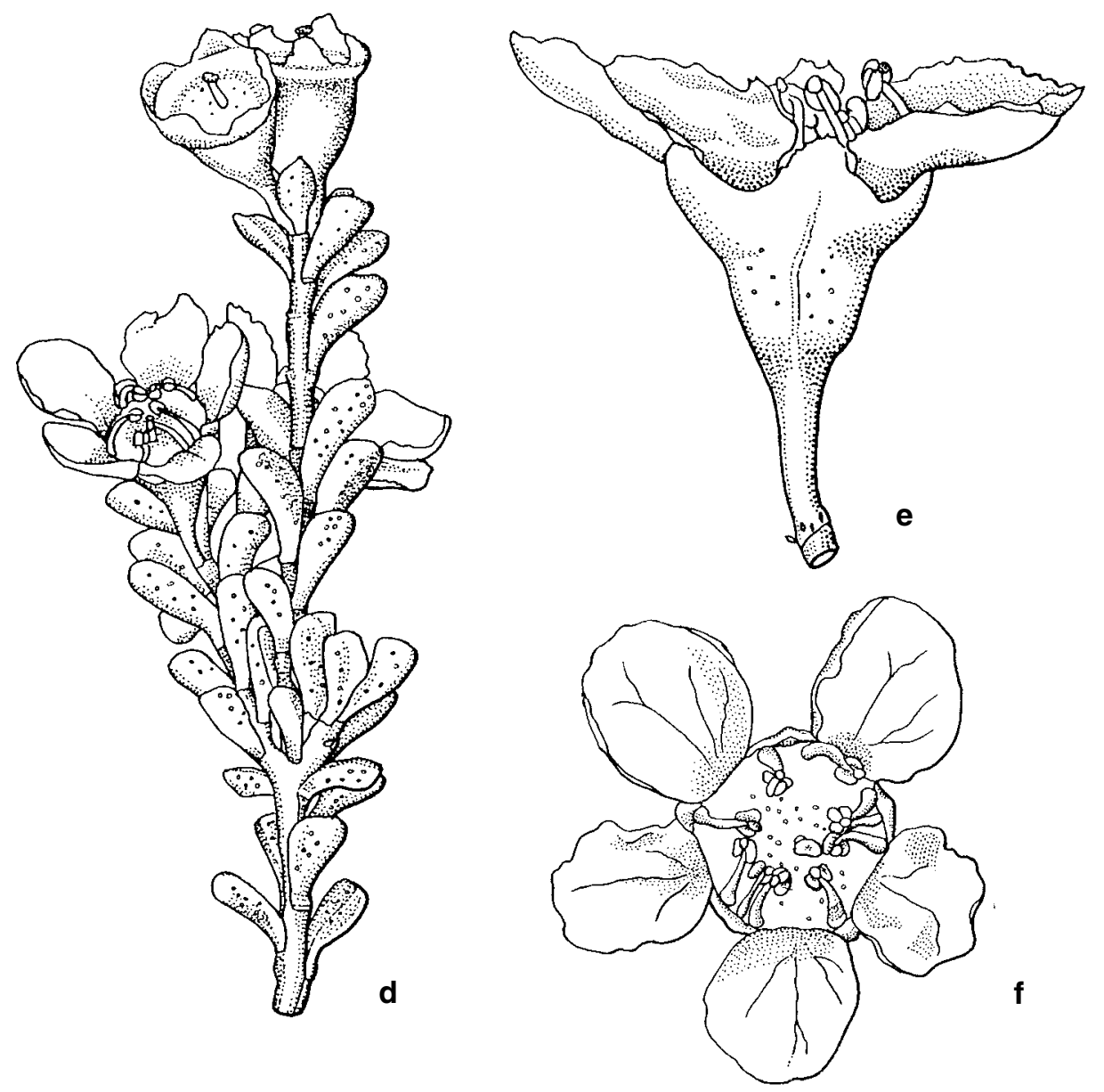

Fig. 4. Baeckea omissa. d, flowering branchlet $(\times 6)$; e, hypanthium and sepals $(\times 12)$; $\mathbf{f}$, petals and stamens $(\times 12)$. $d-f$ from Bean 8258.

petals, all about same length; filaments c. $0.5 \mathrm{~mm}$ long, not glandular; anthers versatile, c. $0.25 \mathrm{~mm}$ long, connective gland brown, c. one quarter as long as anther cells. Style terete, c. $0.6 \mathrm{~mm}$ long at anthesis, stigma slightly capitate. Ovary 1-locular, roof of ovary concave, ovules 15-24, arranged in two longitudinal rows on placenta. Fruit cylindrical, $1.7-2.0 \times 1.7-1.8 \mathrm{~mm}$ in diameter, valves inconspicuous. Seeds c. $1.0 \mathrm{~mm}$ long, pale brown.

Distribution and habitat: Baeckea gunniana is confined to alpine or subalpine regions, from Mt Ginini in the Australian Capital Territory to south-west Tasmania (Fig. 8). It grows with species such as Empodisma minus (Hook. f.) L.A.S. Johnson \& D.F. Cutler, Epacris paludosa R.Br. and Callistemon pityoides, in boggy sedgelands or heathlands or near creeks, and sometimes under light tree cover of Eucalyptus spp. It occurs at high altitudes, mostly 1000-1400 m, but above $2000 \mathrm{~m}$ near Mt Kosciusko, and as low as $450 \mathrm{~m}$ in western Tasmania.

Phenology: flowering occurs from December to April, but mostly between January and March. Fruits can be found throughout the year. 
Affinities: B. gunniana is closely related to B. omissa, but differs by its unilocular ovary and its 4-6 stamens per flower.

Notes: Baeckea gunniana is unique in the genus by virtue of its unilocular ovary, where the pendulous placenta and ovules are enclosed by a single membrane. The two rows of ovules are sometimes spatially separated, suggesting a former division of the ovary, but no such division is evident. The lines of dehiscence on the roof of the ovary (after anthesis) are suggestive of derivation from a 2-locular fruit.

Typification: Ronald Gunn collected B. gunniana on a number of occasions. It is likely that material at both $\mathrm{K}$ and $\mathrm{BM}$ was available to Schauer in drawing up his description. Schauer cited 'Gunn 306' and 'Lawrence 322' in the protologue. I have not seen any Lawrence material, but there are several specimens bearing the Gunn number 306/1842. A specimen at $\mathrm{K}$ from Mt Wellington, with a label bearing two dates is chosen as lectotype because it is the best flowering specimen, and would have been incorporated into the herbarium before Schauer's publication.

Conservation status: B. gunniana is a common and widespread species.

Selected specimens: New South Wales: Southern Tablelands (including A.C.T.): Merritts Ck to Thredbo track, Kosciusko N.P., Taylor 1277 et al., 7 Jan 1981 (CANB, NSW); Jindabyne, Hallman, Mar 1907 (NSW); Big Boggy Creek, 2 km S of Dead Horse Gap, c. 10 km SSE of Mt. Kosciusko, Briggs 3318, 28 Mar 1970 (NSW); Kiandra district, Betche, Feb 1897 (NSW); Mt Ginini, 15.7 miles [25.1 km] past Bull's Head settlement, Canning EMC624, 9 Jan 1968 (CANB); Bimberi Peak, Cambage 3443, Jan 1912 (NSW).

Victoria: Davies Plain, Benambra-Tom Groggin track, 50 miles [80 km] SW of Jindabyne, Hall FRI13661, 12 Jan 1966 (CANB); beside Pretty Valley Dam, Bogong N.P., Norris 312, 6 Feb 1985 (BRI, NSW); far SW of Mt Buffalo plateau, Willis s.n., 18 Feb 1963 (MEL, NSW); The Bluff, Walsh 951, 22 Jan 1981 (MEL, NSW); 2.7 km SE of Hotham Heights General Store, on road to Omeo, Albrecht 223 E Conn, 23 Feb 1984 (MEL, NSW); Forlorn Hope Plain, Beauglehole ACB35257 \& Finck, 19 Jan 1971 (CANB, MEL); Blue Range road, near the crossing at Storm Creek, Corrick 8581, 2 Jan 1983 (CANB, $\mathrm{HO}, \mathrm{MEL}, \mathrm{NSW})$.

Tasmania: Mount Field: Mt Field N.P., 1 km E of Lake Dobson, Croft 10030 E Richardson, 14 Feb 1989 (CANB, HO, MEL, NSW). Central Highlands: c. $8 \mathrm{~km} \mathrm{~W}$ of Liawenee on road to Lake Augusta, Davies 975 et al., 17 Jan 1989 (AD, CANB, HO, MEL); road to Mt Rufus canal, Jarman s.n., 14 Feb 1985 (HO). Ben Lomond: Ben Lomond N.P., Hamilton Crags, 1.5 km E of Legges Tor, Davies 1190 et al., 23 Jan 1989 (AD, CANB, HO, MEL). Mt Wellington: top of Table Mountain [Mt Wellington], near Derwent River, Brown, Mar 1804 (BM, CANB, MEL, NSW). West Coast: head of gully between Reeds Peak and Great Dome, Denison Range, Buchanan 12976, 30 Jan 1993 (HO). South West: Hartz Mountains, Olsen s.n., 22 Jan 1939 (HO).

9. Baeckea kandos A.R.Bean, sp. nov.

B. utili affinis sed ramulis glandes oleaceas gerentibus, foliis angustioribus, petalis 1.5-1.9 mm diam., stipitibus 1.0-1.5 mm longis, staminibus 10-12 differens.

Typus: New South Wales: Dunn Swamp, Kandos Weir, 26 km NE of Kandos, 3250'S $150^{\circ} 12^{\prime} \mathrm{E}$, A.J. Ford 136, 2 January 1990 (holo NSW; iso PERTH).

Baeckea sp. E, Wilson in Harden (ed.), Flora of N.S.W. 2: 185 (1991).

Shrub to $2 \mathrm{~m}$ high. Bark unknown. Branchlets pink, segments flat, not flanged, margins entire; oil glands present. Leaves solitary at each node, linear to linearoblanceolate, straight, concavo-convex, not keeled, 3.3-5.8 mm long, 0.6-1.0 mm wide, oil glands visible on both surfaces, scattered, midvein not visible, margins entire, apex obtuse, base cuneate; petioles c. $0.5 \mathrm{~mm}$ long. Peduncles c. $0.3 \mathrm{~mm}$ long; pedicels 1.0-1.5 mm long, bracteoles linear, c. $1.0 \mathrm{~mm}$ long, caducous before anthesis, apex acute, margins entire. Hypanthium obconical, 1.7-2.1 mm long, smooth, fused to the ovary except distally. Sepals simple, semi-orbicular, $0.5-0.6 \times 0.7-0.8 \mathrm{~mm}$, thin, apex 
obtuse, margins entire. Corolla up to $5 \mathrm{~mm}$ across; petals white, orbicular, $1.5-1.9 \times$ $1.5-1.9 \mathrm{~mm}$, oil glands present, margins entire. Stamens $10-12$, in groups of 1-3 opposite the sepals, some longer than others; filaments c. $0.8 \mathrm{~mm}$ long, not glandular; anthers versatile, c. $0.3 \mathrm{~mm}$ long, connective gland brown, c. one-quarter as long as anther cells. Style terete, c. $0.5 \mathrm{~mm}$ long at anthesis, stigma broadly capitate. Ovary 2locular, roof of ovary concave, ovules 12 or 13 per loculus, arranged in two longitudinal rows on placenta. Fruit cylindrical, c. $1.6 \times 1.9 \mathrm{~mm}$, valves inconspicuous, not woody. Seeds c. $0.7 \mathrm{~mm}$ long, brown. Fig. 4, g-i.

Distribution and habitat: $B$. kandos is apparently confined to the Kandos Weir area in New South Wales, where it is known from two small populations (Fig. 2). It grows in heathland or shrubland species including Leptospermum parvifolium Sm., L. arachnoides Gaertn. and Grevillea diffusa Spreng., on skeletal sandy soil derived from sandstone.

Phenology: flowering is recorded for December and January.

Affinities: $B$. kandos is closely related to $B$. utilis, but differs by its leaves $0.6-1.0 \mathrm{~mm}$ wide (0.9-2.3 $\mathrm{mm}$ for utilis); pedicels $1.0-1.5 \mathrm{~mm}$ long (1.6-2.5 $\mathrm{mm}$ for utilis); oil glands present on branchlets (absent for utilis); petals $1.5-1.9 \mathrm{~mm}$ in diameter (1.9-2.5 $\mathrm{mm}$ for utilis) and stamens 10-12 (8-10 for utilis).

Conservation status: the risk category for Baeckea kandos according to the criteria of Chalson \& Keith (1995) is 'endangered' (criteria A, D). Two small populations are known a few hundred metres apart, in Wollemi National Park, and the total number of plants is fewer than 100. Furthermore some unsucessful searches have been made in nearby areas of similar habitat (A. Ford pers. comm. 1997).

Etymology: the specific epithet refers to the town of Kandos, near where the type was collected.

Specimens examined: New South Wales: Central Western Slopes: Dunn Swamp/Kandos Weir, c. 24 km NE Kandos, Ford 188, 30 Dec 1990 (NSW); Dunn's Swamp, Wollemi N.P., east of Kandos, Ford 1001, 1002, 1003, 28 Dec 1992 (NSW).

10. Baeckea utilis F.Muell. ex Miq., Ned. Kruidk. Arch. 4: 150 (1856).

Type: Victoria: Buffalo-range Nov. Holl. austr., F. Mueller, February-March 1853 (holo MEL).

Shrub to $4 \mathrm{~m}$ high. Bark grey, scaly, persistent. Branchlets yellowish to grey, segments flat, slightly flanged, margins entire; oil glands absent. Leaves solitary at each node, narrowly obovate to elliptical, straight, triangular in cross-section, concavo-convex, keeled or not keeled, 3.4-7.0 mm long, 0.9-2.3 mm wide, oil glands visible on both surfaces, midvein not visible, margins entire, apex obtuse or acute, base cuneate; petioles $0.5-0.8 \mathrm{~mm}$ long. Peduncles absent; pedicels $1.6-2.5 \mathrm{~mm}$ long, bracteoles linear, 1.0-1.4 mm long, persistent to anthesis, apex acute to acuminate, margins entire. Hypanthium obconical, $2.0-2.5 \mathrm{~mm}$ long, smooth, fused to the ovary except distally. Sepals simple, oblong, $0.5-1.0 \times 0.7-1.0 \mathrm{~mm}$, thickened in centre, apex obtuse, margins entire. Corolla up to $5.5 \mathrm{~mm}$ across; petals white, orbicular, 1.9-2.5 $\times 1.9-2.5 \mathrm{~mm}$, oil glands present, margins entire. Stamens $8-10$, in groups of 1-3 opposite the sepals, all about same length; filaments c. $1.2 \mathrm{~mm}$ long, not glandular; anthers versatile, c. $0.5 \mathrm{~mm}$ long, connective gland brown, c. one-third as long as anther cells. Style terete, c. $1.4 \mathrm{~mm}$ long at anthesis, stigma broadly capitate. Ovary 2-locular, roof of ovary concave, ovules 11-15 per loculus, arranged in two longitudinal rows on placenta. Fruit hemispherical, 1.7-2.0 × 2.7-3.0 mm in diameter, valves inconspicuous. Seeds not seen.

Distribution and habitat: Baeckea utilis is common at high altitudes in eastern Victoria, southern New South Wales, and the Australian Capital Territory, with disjunct occurrences in the Blue Mountains-Rylstone area and New England National Park 

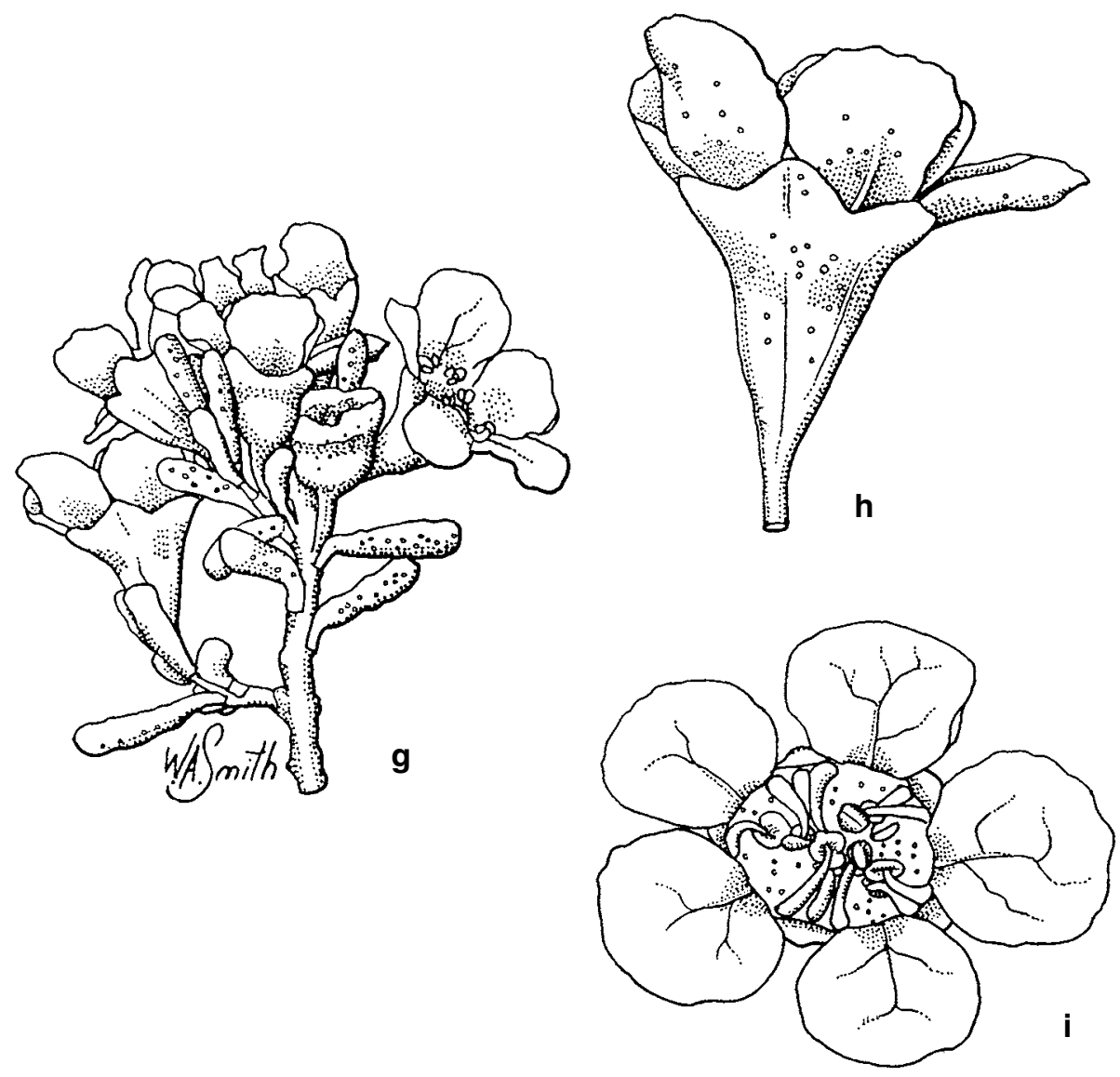

Fig. 4. Baeckea kandos. g, flowering branchlet $(\times 6)$; $\mathbf{h}$, hypanthium and sepals $(\times 12)$; $\mathbf{i}$, petals and stamens $(\times 12)$. $\mathrm{g}-\mathrm{i}$ from holotype.

near Ebor (Fig. 7). It grows on alpine herbfields, montane swamp and wet heathlands, with species such as Casuarina nana Spreng., Leptospermum spp., Epacris paludosa, Restio australis R.Br. and Baeckea gunniana.

Phenology: flowering occurs from December-March; fruiting throughout the year.

Affinities: B. utilis is related to B. kandos and B. latifolia (see notes under those species). It is distinguishable from B. gunniana by its 2-locular ovary, longer leaves, longer pedicels and 8-10 stamens per flower.

Conservation status: B. utilis is a common and widespread species.

Selected specimens: New South Wales: Northern Tablelands: Butchers Creek, Stewarts Brook S.F., between Gloucester and Scone, Bean 11514, 13 Dec 1996 (BRI, NSW); New England N.P., next to carpark at Banksia Point, Sparshott KMS324 \& Sparshott, 18 Sep 1994 (BRI, MEL, NSW). Central Western Slopes: head of Cudgegong River, NW of Rylstone, Whaite 941, 12 Aug 1951 (NSW); 1.4 km from Dunns Swamp, Wollemi N.P., east of Rylstone, Bean 9406, 25 Dec 1995 (BRI, MEL, NSW). Central Tablelands: Murray's Swamp, just off Glow Worm Tunnel road, $4.6 \mathrm{~km}$ NE of the Bungleboori picnic area, Newnes S.F., Coveny 13951 \& Hind, 28 Dec 1989 (CANB, HO, MEL, NSW); 
Wentworth Falls, Cambage 1935, 4 Jan 1908 (NSW). Southern Tablelands (including A.C.T.): White Rock plateau between Mt Wog Wog and White Rock, Nalbaugh N.P., Albrecht 1646, 26 Mar 1985 (CANB, HO, MEL, NSW); Tuross River area, Craven 2523, 8 Jan 1974 (A, CANB, L, NSW, PERTH); Frog Porridge Hollow, north watershed of Goobragandra River, Schodde, Mar 1965 (A, CANB, K, L, NSW); Mt Bimberi, Namadgi N.P., Gilmour 6520, Jan 1988 (CANB); Brindabella Range, Mt Gingera, Snowy Flat, Crisp 6408, Jan 1980 (CANB, NSW).

Victoria: Midlands: Worragee, 12 km NNE of Beechworth, Johnson 7, 16 Aug 1989 (MEL). Eastern Highlands: 0.4 km east of Back Creek junction, Forbes SJF239, 7 Jan 1980 (MEL, NSW); c. 9 km E of Mt Little Tambo, c. $0.5 \mathrm{~km}$ NE from junction of Currawong road and McDougall Spur track, Davies 595 et al., 10 Nov 1988 (CANB, MEL, NSW). Snowfields: Bogong Range, Brooker 5534, Feb 1977 (CANB); W side of Bogong High Plains road, 25.6 km ESE of Falls Creek, Jobson 4119, Feb 1996 (BRI, CANB, MEL); near Native Cat track, c. 40 km E of Benambra, Bean 9441 \& Jobson, Dec 1995 (BRI, MEL); Buffalo Plateau, Collier 2425, 21 Apr 1987 (HO). East Gippsland: Bendock area, Delegate River, Gunmark road, Paris s.n., 1 Jan 1982 (MEL, NSW); Maramingo Creek swamp, 7 km E of Genoa, Bean 9419 \& Jobson, Dec 1995 (BRI, CANB, MEL, NSW).

11. Baeckea latifolia (Benth.) A.R. Bean, comb. et stat. nov.

Basionym: Baeckea gunniana var. latifolia Benth., Fl. Austral. 3: 79 (1867); Baeckea utilis var. latifolia (Benth.) J.H. Willis, Muelleria 1: 139 (1967).

Type: Victoria: Baw Baw Mountains, F. Mueller s.n., undated (holo K; iso BM, MEL).

Shrub to $1.5 \mathrm{~m}$ high. Bark scaly to fibrous, persistent, grey. Branchlets pink to grey, segments flat, slightly flanged, margins entire; oil glands present. Leaves solitary at each node, broadly elliptical, straight, flat, not keeled, 6.4-9.0 mm long, 2.3-5.3 mm wide, oil glands visible on both surfaces, midvein not visible, margins entire and translucent, apex obtuse or acute, base cuneate; petioles 1.2-1.5 mm long. Peduncles c. $0.5 \mathrm{~mm}$ long; pedicels $3.0-3.3 \mathrm{~mm}$ long, bracteoles narrowly ovate, $1.6-2.1 \mathrm{~mm}$ long, caducous before anthesis, apex acute, margins entire. Hypanthium obconical, 2.5-3.0 $\mathrm{mm}$ long, smooth, fused to the ovary except distally. Sepals simple, oblong, $1.2-1.4 \times$ $1.5-1.9 \mathrm{~mm}$, thin, apex obtuse, margins entire. Corolla up to $9 \mathrm{~mm}$ across; petals white, orbicular, $2.7-3.0 \times 3.0-3.2 \mathrm{~mm}$, oil glands present, margins entire. Stamens $6-8$, in groups of 1-3 opposite sepals, all about same length; filaments c. $1.0 \mathrm{~mm}$ long, not glandular; anthers versatile, c. $0.5 \mathrm{~mm}$ long, connective gland brown, c. one-third as long as anther cells. Style terete, c. $1.5 \mathrm{~mm}$ long at anthesis, stigma slightly to broadly capitate. Ovary 2-locular, roof of ovary flat or concave, ovules 17 or 18 per loculus, arranged in two longitudinal rows on placenta. Fruit cylindrical, 3.0-3.8 $\times 2.5-2.8 \mathrm{~mm}$ in diameter, valves inconspicuous. Seeds not seen. Fig. 5, a-c.

Distribution and habitat: Baeckea latifolia is confined to several mountains and ranges in Victoria and New South Wales (Fig. 6). It grows as an understorey species in Eucalyptus pauciflora Spreng. woodland, in association with species such as Oxylobium alpestre F. Muell., Hovea montana (Hook. f.) J.H. Ross, Richea continentalis B.L. Burtt, Tasmannia vickeriana (A.C. Sm.) A.C. Sm. and Wittsteinia vacciniacea F. Muell. Altitudes range from 1400 to 1700 metres.

Phenology: flowers are recorded for January and February; fruits can be found throughout the year.

Affinities: B. latifolia is related to B. utilis but differs by its leaves $2.3-5.3 \mathrm{~mm}$ wide (0.9-2.3 mm for utilis), its longer and broader sepals, 17 or 18 ovules per loculus (11-15 for utilis), larger petals and longer fruits.

Notes: B. latifolia is reported from Mt Gingera in the Australian Capital Territory (Burbidge \& Gray 1970), but no specimens have been seen from there. 
A sterile specimen from Barren Mountain, west of Dorrigo (J.B. Williams 72-155, 11 July 1972 (NSW)) greatly resembles B. latifolia, but judgement is reserved until fertile material is available.

Conservation status: B. latifolia is of limited occurrence in subalpine areas of southern New South Wales and eastern Victoria. However, it is nearly always locally common where it occurs (N. Walsh pers. comm.), so it should probably not be regarded as Rare or Threatened.

Specimens examined: New South Wales: Southern Tablelands: near Schlink Pass, Thompson 2903, Feb 1978 (NSW); Boobee Hut, Happy Jacks Plains, Snowy Mtns, Carroll s.n., 17 Jan 1966 (CANB). Victoria: Snowfields: above Baw Baw village, Gunn s.n., 31 Jan 1970 (CANB); Mt Baw Baw, c. 200 m NW of village towards summit, Jobson 4084, 26 Jan 1996 (BRI, MEL); track to Boggy Ck, Mt Buller, east of Mansfield, Bean 9475 \& Jobson, 1 Jan 1996 (BRI, MEL); Mt Buller, Boggy Creek area, Huggins s.n., 31 Jan 1983 (MEL, NSW); Mt Buller, top of Old Hut Spur, Walsh 1238, 27 Jan 1981 (MEL); Lake Mountain, Stajsic 195, 10 Feb 1991 (MEL).

12. Baeckea brevifolia (Rudge) DC., Prodr. 3: 230 (1828).

Leptospermum brevifolium Rudge, Trans. Linn. Soc. London, Botany 8: 299 (1807).

Type: in Nova Hollandia, collector unknown, undated (holo BM n.v., photo BRI)

Baeckea carnosula Sieber ex Spreng., Syst. Veg. 4: 149 (1827).

Type: Nov. Holl., F.W. Sieber 278, 1823 (iso BM, GH).

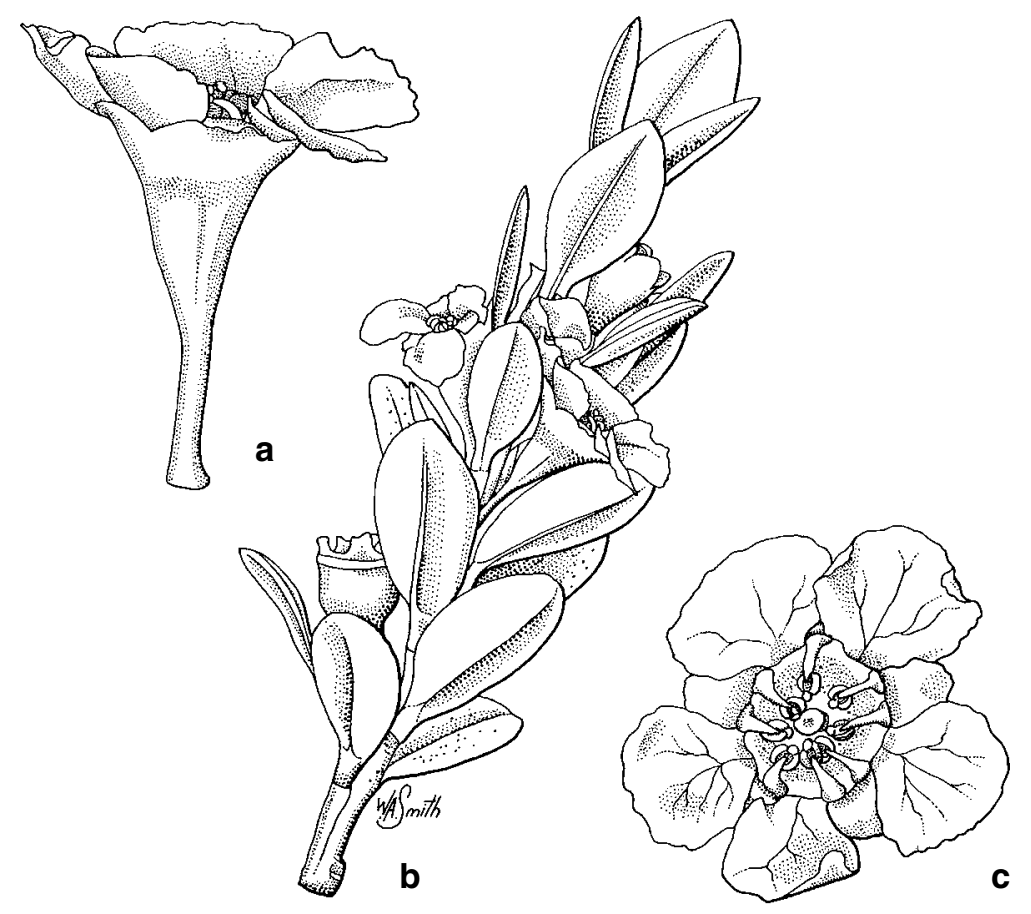

Fig. 5. Baeckea latifolia. a, flowering branchlet $(\times 6)$; b, hypanthium and sepals $(\times 12)$; c, petals and stamens $(\times 12)$. a-c from Jobson 4084. 


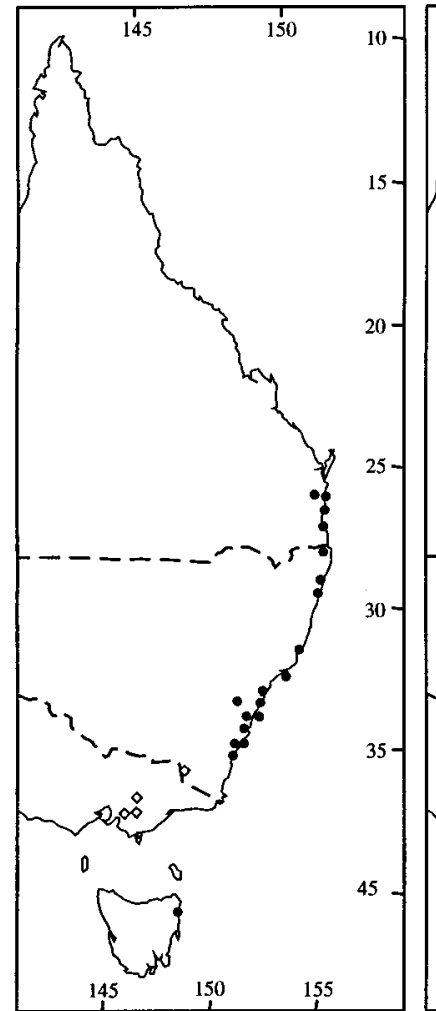

Fig. 6.

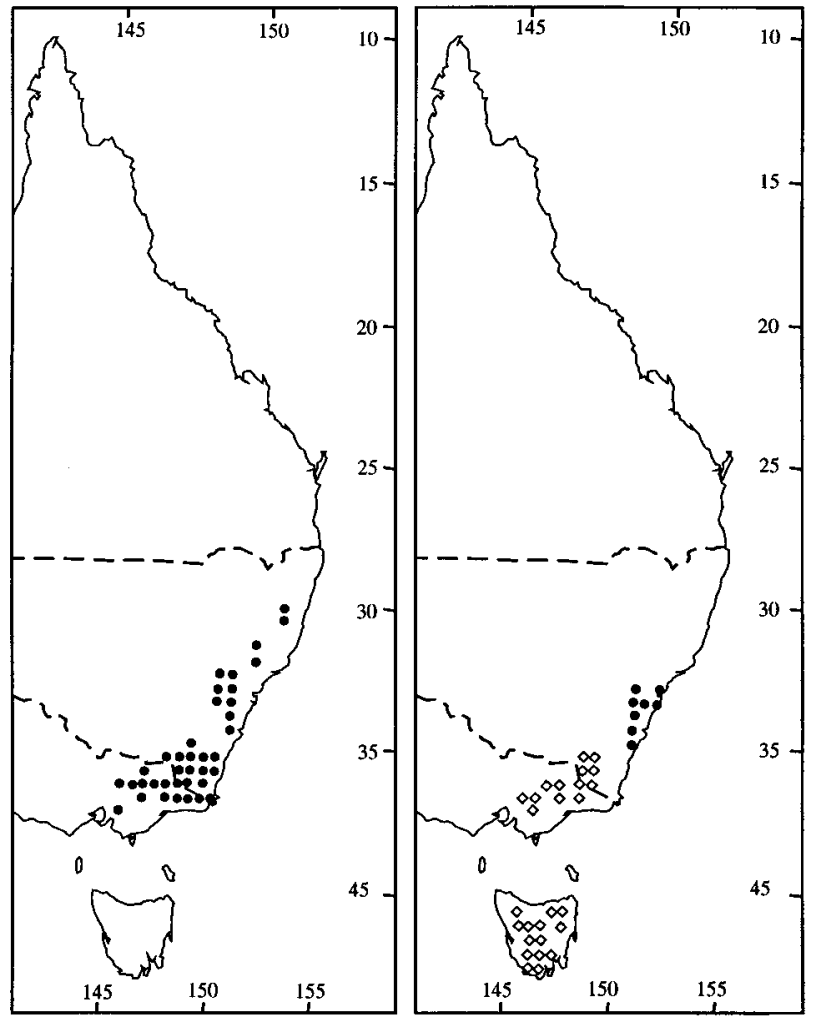

Fig. 7.
Fig. 8.

Fig. 6. Distribution of Baeckea imbricata $\bowtie ;$ Baeckea latifolia $\diamond$.

Fig. 7. Distribution of Baeckea utilis $₫$

Fig. 8. Distribution of Baeckea gunniana $\diamond$; Baeckea brevifolia $\bowtie$.

Shrub to $0.8 \mathrm{~m}$ high. Bark grey, fibrous. Branchlets grey, segments convex, not flanged, margins entire; oil glands absent. Leaves solitary at each node, elliptical, straight, concavo-convex, not keeled, 1.0-2.3 mm long, 0.7-1.0 mm wide, oil glands visible on both surfaces, scattered, midvein not visible, margins entire or irregular, apex obtuse, base cuneate; petioles absent. Peduncles absent or up to $0.5 \mathrm{~mm}$ long; pedicels $0.4-1.5 \mathrm{~mm}$ long, bracteoles linear, c. $0.9 \mathrm{~mm}$ long, caducous before anthesis, apex acute, margins entire. Hypanthium obconical, 1.5-2.5 mm long, smooth, fused to the ovary except distally. Sepals compound, inner lobes semi-orbicular, $0.5-1.0 \times 1.2-2.0 \mathrm{~mm}$, thin, apex obtuse; outer lobes gibbous, $0.5-1.2 \times 1.0-1.5 \mathrm{~mm}$, thick, apex acute to obtuse, margins entire, sometimes exceeding inner lobe. Corolla up to $7.5 \mathrm{~mm}$ across; petals white or pale pink, orbicular, 1.9-2.5 × 1.9-2.5 mm, oil glands present, margins entire. Stamens $8-17$, in groups of $2-4$ opposite the sepals, stamen opposite calyx lobe shorter than remainder; filaments $0.6-1.3 \mathrm{~mm}$ long, not glandular; anthers versatile, c. $0.5 \mathrm{~mm}$ long, connective gland brown, c. 0.25 times as long as anther cells. Style terete, c. $1.0 \mathrm{~mm}$ long at anthesis, stigma slightly capitate. Ovary 2-locular, roof of ovary concave, ovules 6-9 per loculus, arranged in two longitudinal rows on placenta. Fruit cylindrical, $1.7-2.0 \times 1.5-1.7 \mathrm{~mm}$ in diameter, valves inconspicuous. Seeds not seen. 
Distribution and habitat: Baeckea brevifolia is restricted to the cental coast of New South Wales and the adjacent tablelands, from Woy Woy to Milton (Fig. 8). It inhabits sandstone rock pavements and the small depressions within them, in association with a wide range of heathy species, including Leptospermum parvifolium, Petrophile pulchella (Schrad. \& J.C.Wendl.) R.Br., Babingtonia densifolia (Sm.) F.Muell., Leucopogon microphyllus (Cav.) R.Br. and Calytrix tetragona Labill. Altitudes are mostly 100-800 metres, but it reaches $1240 \mathrm{~m}$ in the Kanangra Boyd N.P.

Phenology: flowers have been recorded mostly from January to May, with one record in October; fruits can be found for most of the year.

Affinities: $B$. brevifolia is a very distinctive species, not only because of its thick, sessile leaves, numerous stamens, compound sepals and few ovules, but because of its habitat (sandstone rocks), which is quite unlike that of most other Baeckea spp.

Conservation status: B. brevifolia is a common and widespread species

Selected specimens: New South Wales: Central Coast: Berowra, Boorman s.n., Mar 1918 (A); between Port Jackson and South Head, Brown, 5 May 1805 (NSW); Peats Bight Fire Trail, c. 5 km NNE of Cowan, Muogamarra N.R., Coveny 15525 et al., 22 Aug 1991 (BRI, CANB, HO, MEL, NSW); The Valley, Blue Mtns [Springwood], Fletcher s.n., 1 Apr 1888 (NSW); The Lookout, Woy Woy, McBarron 17578, 25 Aug 1969 (NSW); N of Oxford Falls road, near junction with Spicer road, Oxford Falls, c. $2.5 \mathrm{~km}$ NE of Frenchs Forest, Whalen 6 \& Coveny, 19 Feb 1993 (MEL, NSW). Central Tablelands: northern side of Flat Top, NW of Katoomba, Benson 1542 \& Keith, 11 Nov 1983 (NSW); Mt Wilson, Evans, Mar 1927 (CANB); Mt Colong, Constable, 4 Mar 1948 (NSW); Wentworth Falls, Hamilton, Apr 1914 (NSW); Wingello S.F., $0.75 \mathrm{~km} \mathrm{~W}$ of end of Bulls Ridge Rd, Fulton 61, 12 Jan 1995 (CANB, NSW); Kanangra Walls, near carpark, Kanangra Boyd N.P., Davies 2 \& Errington, 2 May 1996 (NSW); Nayook Ck, Wollemi N.P., 25.8 km NNE of Clarence, Coveny 15150 \& Hind, 27 Jan 1991 (MEL, NSW). South Coast: 5 km SSE of Mt Tianjara, Adams \& Paijmans 3776, 26 Mar 1981 (CANB, NSW); Turpentine Range, Nowra-Nerriga Rd, Constable, Oct 1957 (NSW); 2 km S of Wilban Hill, Ettrema Plateau, W of Nowra, Briggs 3007, 15 Mar 1969 (NSW); 9.5 km W of Nowra turnoff on Nerriga road, Howe 101, 12 Feb 1984 (CANB, MEL, NSW). Southern Tablelands: $7.5 \mathrm{~km}$ S of Sassafras, Seur 206, 9 Mar 1975 (NSW); 12.9 km ESE of Nerriga, Pickard 1678, 5 Sep 1971 (NSW); Mt Sassafras, c. 17 miles [27 km] E of Nerriga, Hartley 14280, 25 Mar 1975 (NSW).

\section{Unplaced names}

Baeckea spinosa Sieber ex Spreng., Syst. Veg. 4: 149 (1827).

Baeckea virgata var. polyandra Maiden \& Betche, Proc. Linn. Soc. New South Wales 23: 12 (1898).

\section{Excluded names for Eastern Australia, New Caledonia, Malesia and south-east Asia (arranged chronologically)}

Baeckea densifolia Sm., Trans. Linn. Soc. London 3: $260(1797)$ = Babingtonia densifolia (Sm.) F. Muell.

Baeckea virgata (J.R. Forst. \& G. Forst.) Andrews, Bot. Repos. 9: t. 598 (1810) = Babingtonia virgata (J.R. Forst. \& G. Forst.) F. Muell.

Baeckea gracilis A. Cunn. in Field, Geog. Mem. N.S.W. 349 (1825) = Micromyrtus ciliata (Sm.) Druce

Baeckea camphorata R.Br. ex Sims, Bot. Mag. 53, t. 2694 (1826) = Triplarina imbricata (Sm.) A.R. Bean

Baeckea fasciculata Sieber ex Spreng., Syst. Veg. 4: 149 (1827) = Babingtonia densifolia (Sm.) F. Muell.

Baeckea microphylla Sieber ex Spreng., Syst. Veg. 4: 149 (1827) = Micromyrtus ciliata (Sm.) Druce

Baeckea micrantha DC., Prodr. 3: 230 (1828) = Thryptomene baeckeacea F. Muell. 
Baeckea parvula (Labill.) DC., Prodr. 3: 229 (1828) = Babingtonia virgata (J.R. Forst. \& G. Forst.) F. Muell.

Baeckea pinifolia (Labill.) DC., Prodr. 3: 229 (1828) = Babingtonia pinifolia (Labill.) A.R. Bean Baeckea calycina Lindl. in Mitchell, Three Exped. interior East. Aust. 2: $189(1838)=$ Thryptomene calycina (Lindl.) Stapf

Baeckea phylicoides Schauer in Walp., Repert. Bot. Syst. 2: 921 (1843) = Kunzea ericoides (A. Rich.) Joy Thomps.

Baeckea leptocalyx F. Muell., Fragm. 1: 30 (1858) = Micromyrtus leptocalyx (F. Muell.) Benth. Baeckea plicata F. Muell., Fragm. 1: 30 (1858) = Micromyrtus ciliata (Sm.) Druce

Baeckea obtusifolia Brongn. \& Gris, Bull. Soc. Bot. France 11: 185 (1864) = Babingtonia virgata (J.R. Forst. \& G. Forst.) F. Muell.

Baeckea nelitroides Seem., J. Bot. 2: $74(1864)=$ Cloezia floribunda Brongn. \& Gris

Baeckea behrii (Schltdl.) F. Muell., Fragm. 4: 68 (1864) = Babingtonia behrii (Schltdl.) A.R. Bean Baeckea crenatifolia F. Muell, Fragm. 4: 70 (1864) = Babingtonia crenulata (F. Muell.) A.R. Bean Baeckea nova-anglica F. Muell., Fragm. 4: 71 (1864) = Babingtonia densifolia (Sm.) F. Muell.

Baeckea ericoides Brongn. \& Gris, Bull. Soc. Bot. France 11: 184 (1864), non B. ericoides Schltdl. = Babingtonia leratii (Schltr.) A.R. Bean

(Schauer) Benth., Fl. Austral. 3: 82 (1867) = Babingtonia cunninghamii (Schauer) A.R. Bean Baeckea oligomera Radlk., Ber. Deutsch. Bot. Ges. 2: 264 (1884) = Ochrosperma oligomerum (Radlk.) A.R. Bean

Baeckea intratropica (F. Muell.) Nied., Nat. Pfl. Fam. 3(7): 99 (1893) = Astartea intratropica F. Muell.

Baeckea leratii Schltr., Bot. Jahrb. Syst. 40, Beibl. 92: 32 (1908) = Babingtonia leratii (Schltr.) A.R. Bean

Baeckea taxifolia Merr., Sarawak Mus. J. 3: 534, 537 (1928) = Babingtonia taxifolia (Merr.) A.R. Bean

Baeckea squarrulosa Domin, Biblioth. Bot. 89: 450 (1928) = Babingtonia squarrulosa (Domin) A.R. Bean

Baeckea linearis C.T. White, Proc. Roy. Soc. Queensland 55: 65 (1944) = Ochrosperma lineare (C.T. White) Trudgen

Baeckea citriodora A.R. Penfold \& J.H. Willis, J. \& Proc. Roy. Soc. New South Wales 89: $186(1956)=$ Ochrosperma citriodorum (A.R. Penfold \& J.H. Willis) Trudgen

Baeckea jucunda S.T. Blake, Proc. Roy. Soc. Queensland 69: 75 (1958) = Babingtonia jucunda (S.T. Blake) A.R. Bean

Baeckea procera J.W. Dawson, Fl. Nouv. Caledon. et Dep. 18: 22 (1992) = Babingtonia procera (J.W. Dawson) A.R. Bean

\section{Acknowledgments}

I would like to thank Laurie Jessup (ABLO 1993-94) for photographing type specimens, and the Directors of A, BM, CANB, G, GH, HAL, HO, K, L, MEL, NE, NSW and QRS for the loan of specimens or access to their Herbaria. Peter Jobson assisted with field work in Victoria and collected specimens, Jian Wang translated a Chinese botanical description, Andrew Ford offered information on B. kandos, Peter Bostock provided the Latin diagnoses, and Will Smith (BRI) provided the illustrations.

\section{References}

Anon. (1972) Iconographia Cormophytorum Sinicorum 2: 1000. (Science Press: Beijing).

Bean, A.R. (1995) Reinstatement and revision of Triplarina Raf. (Myrtaceae). Austrobaileya 4(3): 353-67. 
Bean, A.R. (1997a) Reinstatement of Babingtonia Lindl. (Myrtaceae, Leptospermoideae). Austrobaileya 4(4): 627-46.

Bean, A.R. (1997b) Myrtaceae (in part). In R.J.F. Henderson (ed.), Queensland Plants: Names and Distribution. (Queensland Department of Environment: Brisbane).

Bentham, G. (1865) Baeckea. In Bentham \& Hooker, Genera Plantarum. (L. Reeve \& Co.: London).

Burbidge, N.T. \& Gray, M. (1970) Flora of the Australian Capital Territory. (Australian National University Press: Canberra).

Chalson, J.M. \& Keith, D.A. (1995). A Risk Assessment scheme for Vascular Plants: Pilot Application to the Flora of New South Wales. (National Parks and Wildlife Service: Hurstville).

Merrill, E. (1935) A Commentary on Loureiro's Flora Cochinchinensis. (The American Philosphical Society: Philadelphia).

Thompson, J. \& Gray, M. (1981) A Checklist of Subalpine and Alpine Plant Species found in the Kosciusko region of New South Wales. Telopea 2(3): 299-346.

Trudgen, M.E. (1986) Reinstatement and revision of Rinzia Schauer (Myrtaceae, Leptospermeae, Baeckeinae). Nuytsia 5(3): 415-40.

Trudgen, M.E. (1987) Ochrosperma, a new genus of Myrtaceae (Leptospermeae, Baeckeinae) from New South Wales and Queensland. Nuytsia 6: 9-17.

Manuscript received 21 July 1997

Manuscript accepted 10 November 1997 